\title{
Formation mechanism of the Vaasa Batholith in the Fennoscandian Shield: petrographic and geochemical constraints
}

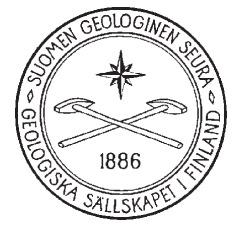

\author{
Hannu Mäkitie $^{1) *}$, Pekka Sipilä ${ }^{1)}$, Hannu Kujala ${ }^{1)}$, Antero \\ LINDBERG $^{1)}$ AND ANNA KOTILAINEN ${ }^{2)}$ \\ 1) Geological Survey of Finland, FI-02151 Espoo, Finland \\ 2) University of Helsinki, Division of Geology, FI-00014 University of Helsinki, Finland
}

\begin{abstract}
The $\sim 1.88 \mathrm{Ga}$ Vaasa Batholith in western Finland is a large granitoid area $\left(8000 \mathrm{~km}^{2}\right)$ with gradational contacts against the garnet- and cordierite-bearing diatexite and metatexite migmatites of the Pohjanmaa Belt. It is located in the middle part of the Fennoscandian Shield and was formed during the Svecofennian orogeny (1.9-1.8 Ga). The Batholith area consists of porphyritic and even-grained granodiorite with smaller proportions of granite and pyroxene granitoid. The various phases in the Vaasa Batholith mainly grade into each other and usually contain relicts of Ca concretions and schists, biotite and garnet, locally resembling uniform diatexites. All the phases are peraluminous in composition. The Mg\# of biotite in the granodiorites and pyroxene tonalites is high (50-60), in contrast to lower values in the granite (20-35). Orthopyroxene in the tonalite has an elevated $\mathrm{Mg} \#$ value and $\mathrm{Al}_{2} \mathrm{O}_{3}$ concentration. In Harker diagrams, bulk composition of the tonalites, granodiorites and granites of the Vaasa Batholith evolves along the same path, but the metatexites are beyond or cutting the path. The textural, mineralogical and chemical continuity between the granodiorites of the Vaasa Batholith and the adjacent diatexites indicate that the Vaasa Batholith represents a magma layer formed by extensive in situ melting of the crust. The diatexites are mainly from the inhomogeneous magma, although they texturally grade to the metatexites. The Vaasa Batholith and adjacent diatexites are separated from the metatexites of the Pohjanmaa Belt by 'magma interface' (MI). The metatexites formed in a conduction heat flow zone above the MI. The Vaasa Batholith is an exceptional type example of the voluminous and diverse granitoids in Finland.
\end{abstract}

Keywords: granites, granodiorites, tonalite, migmatites, diatexite, anatexis, geochemistry, magmas, Paleoproterozoic, Vaasa, Finland

* Corresponding author email: hannu.makitie@gtk.fi

Editorial handling: Joonas Virtasalo 


\section{Introduction}

The Precambrian bedrock of the Fennoscandian Shield is the result of several orogenies and major tectonic events (e.g. Gaál \& Gorbatchev, 1987; Nironen, 1997; Koistinen et al., 2001). One important orogeny, the Svecofennian, developed in the Shield - 1.95-1.75 Ga ago, and formed extensive synorogenic 1.89-1.87 Ga intrusive granitoids, late orogenic 1.84-1.81 Ga granitic intrusions and migmatizing granitic pegmatites, and limited postorogenic 1.81-1.77 Ga granite intrusions in central and southern Finland (Lehtinen et al., 2005).

Regional scale crustal melting usually occurs in response to crustal thickening and/or exhumation, or due to the infusion of heat (Brown, 2008). It has been reported from many orogenies and has usually resulted in the formation of granitic rocks of different size. Conditions for the production of granitic melt in crust are controlled by the ambient temperature, protolith fertility and the amount of free water (e.g. Chen \& Grapes, 2007).

The derivation of crustal melt from a metasedimentary source, its subsequent transport and the supply of melt to plutons remains a subject of debate (Wyllie, 1983; White et al., 2001, and references therein). Areas of uncertainty include, for example the mechanism by which the melt escapes its source region and the space problem. Chen and Grapes (2003) have focused on the 'melting interface' or 'magma interface' (MI), which refers to the upper surface of crustal magma layer. The MI also marks the boundary between two heat-flow regimes for crustal melting: convention and conduction. In the convection zone (below MI), melts generated by partial melting become granite magma, whereas in the conduction zone (above MI), melts generated by partial melting are preserved as leucosomes in migmatite.

Gradational changes from migmatites to homogeneous granites are documented from many places (e.g. Chen \& Grapes, 2007, and references therein). Geochemical studies of adjacent migmatites and granitic rocks may clarify the petrogenesis of granitoids. However, field studies at the contacts between granitoids and migmatites remain crucial in distinguishing (par)autochthonous diatexitic granitoids from those granitic intrusions that have ascended to be emplaced within upper crustal rocks.

The Vaasa Batholith in western Finland, in the central part of the Fennoscandian Shield, is a large $\left(8000 \mathrm{~km}^{2}\right.$ ) peraluminous $-1.88 \mathrm{Ga}$ multi-phase coarse-grained granitoid (Laitakari, 1942; Lundqvist \& Autio, 2000; Mäkitie et al., 2008) (Fig. 1). Recent bedrock mapping has determined that the Vaasa Batholith comprises different granitoid types and lacks sharp intrusive contacts with the $-1.9 \mathrm{Ga}$ Svecofennian supracrustal country rocks of the Pohjanmaa Belt (Mäkitie et al., 1999; Mäkitie, 2001a; Lehtonen et al., 2005; Björk et al, 2007; Sipilä et al., 2008). In fact, between the adjacent diatexite migmatites of the Pohjanmaa belt and the variable, often S-type granitoids of the Vaasa Batholith, there is textural, mineralogical and geochemical continuity. These observations suggest that the Vaasa Batholith is derived by partial in-situ melting without significant magma ascent within the crust. Thus, the Vaasa Batholith differs from the typical Svecofennian syn- and postkinematic granitoids nearby, which have sharp intrusive contacts with country rocks (e.g. Mäkitie et al., 1999; Nironen, 2003).

The origin, age and tectonic setting of the Vaasa Batholith have been major problems for several decades, as the granitoids include schist relicts and rounded $\mathrm{Ca}$-concretions, $\mathrm{Al}$-rich accessory minerals and contain highly heterogeneous zircon populations (Väyrynen, 1923; Laitakari, 1942; Alviola et al., 2001). For example, Saksela (1935) suggested that the Vaasa Batholith is a synorogenic granitoid, but Väyrynen (1936) classified parts of it as "late orogenic" (jünger Reihe). The area of the Vaasa Batholith is also sometimes termed the Vaasa Granite (Laitakari, 1942; Helovuori, 1949; Kärkkäinen, 1993; Sipilä et al., 2008) and Vaasa granodiorite (Lundqvist \& Autio, 2000). Mäkitie et al. (1999) called the area the "Vaasa Migmatite Complex". On regional scale geological maps, the area of Vaasa Batholith has been shown as supracrustal rocks (Korsman et al., 1997; Koistinen et al., 2001) or as granitoids (Lundqvist et al., 1996). 


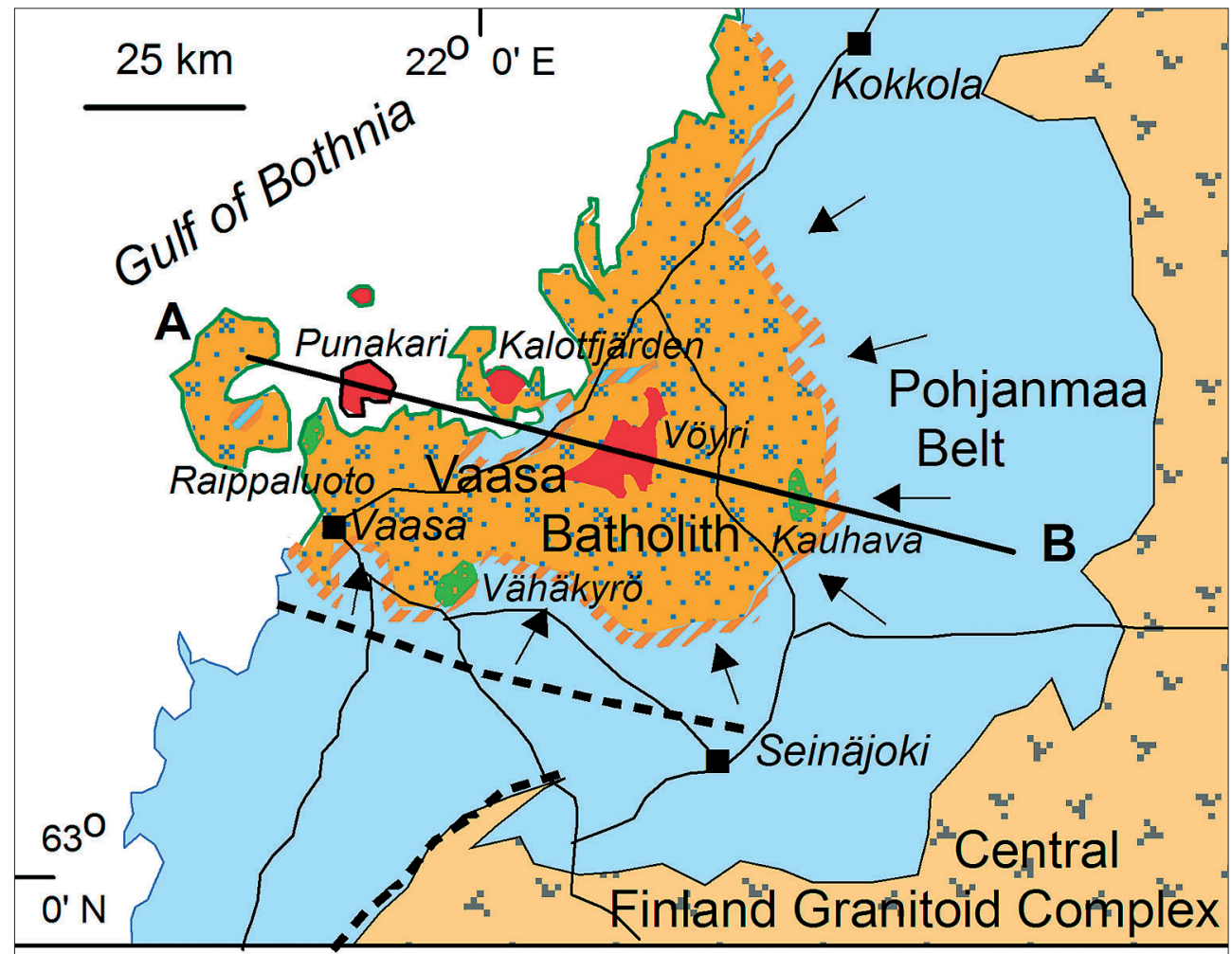

Vaasa Batholith

Granite

Even-grained or porphyritic granodiorite

$\square$ Pyroxene granitoid

\section{Pohjanmaa Belt}

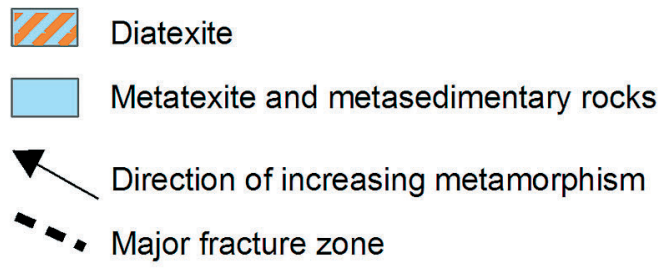

\section{Central Finland Granitoid Complex}

Granite, granodiorite and tonalite

Fig. 1. Geological map of the Vaasa Batholith and its surrounding rocks. The line A-B refers to the position of the cross section of upper crust shown in Figure 12. The map is simplified after Lehtonen et al. (2005), Björk et al. (2007) and Sipilä et al. (2008).

The present paper examines the petrography and geochemistry of the Vaasa Batholith and of the adjacent diatexite and metatexite migmatites of the Pohjanmaa Belt. The formation mechanism of the Vaasa Batholith is also discussed. To date, there has been no coherent English language description of the Vaasa Batholith.

\section{Geological setting}

There are many models for the Svecofennian orogeny. Gaál and Gorbatschev (1987) discussed that, following Palaeoproterozoic intracratonic sedimentation and volcanism, rifting along the present boundary between the Archaean and 
Proterozoic Domains formed a passive continental margin. Activation of this margin occurred at the beginning of the Svecofennian orogeny 2.0-1.75 Ga ago with large scale formation of new continental crust (Gaál \& Gorbatschev, 1987). Nironen (1997) focused on a model having a pre-Svecofennian ocean opening at $1.95 \mathrm{Ga}$ and progressive accretion of two arc complexes onto the Archaean craton 1.91-1.87 Ga ago. Lahtinen et al. (2005) presented a model that has the amalgamation of several microcontinents and island arcs with many pre-1.92 Ga components; resulting in the concept of a separate "semi-continuous" orogenic stages in Svecofennian orogeny. In Finland, the Svecofennian orogeny has resulted in a rather thick crust $(-60 \mathrm{~km})$ and highgrade gneiss terranes are common (Lehtinen et al., 2005). In western Finland, which includes the Vaasa region, the regional metamorphic peak and migmatization were coeval with Svecofennian synorogenic magmatism 1.89-1.88 Ga ago (Vaasjoki \& Sakko, 1988; Alviola et al., 2001).

A $50000 \mathrm{~km}^{2}$ area - a part of the Bothnian Basin - of predominantly -2.0-1.75 Ga Svecofennian marine metasedimentary rocks occurs in the central part of the Fennoscandian Shield (e.g. Hietanen, 1975; Koistinen et al., 2001). In western Finland, this basin area predominantly comprises the Vaasa region, and, in eastern Sweden, the Härnösand-Umeå region. In the centre of the Bothnian Basin, the metasedimentary rock sequence attains thicknesses of $10 \mathrm{~km}$ (Lundqvist, 1987). The Vaasa Batholith lies approximately in the central part of the area. In Finland, the supracrustal rocks around the Vaasa Batholith are referred to as the Pohjanmaa Belt (Nironen et al., 2002). Granitoids and diatexites resembling those in the Vaasa region also occur on the eastern coast of Sweden, but there they are not as homogeneous as on the Finnish side (Leif Björk, 2005, pers. comm.).

Three major geological units can be distinguished in the Vaasa region (Fig. 1). First, there is the $\sim 1.88 \mathrm{Ga}$ Vaasa Batholith. Secondly, the $-1.9 \mathrm{Ga}$ supracrustal rocks of the Pohjanmaa Belt. Lastly, the intrusive 1.89-1.87 Ga Central Finland Granitoid Complex to the east of the Vaasa region. The Pohjanmaa Belt occurs between the Vaasa
Batholith and the Central Finland Granitoid Complex.

The Pohjanmaa Belt is composed of turbiditic pelites and psammites with mafic and intermediate volcanic rocks, graphite-sulphide schists, metacherts, and carbonate rocks as interlayers (Kähkönen, 2005). These supracrustal rocks have undergone multiple deformation events (e.g. Mäkitie, 1999; Lehtonen et al., 2005). The Pohjanmaa Belt also contains small $\sim 1.88 \mathrm{Ga}$ intrusive tonalites and $\sim 1.80 \mathrm{Ga}$ rare-metal pegmatites with pegmatite granite swarms (Alviola et al., 2001). The extensive Central Finland Granitoid Complex in the east is mainly composed of syn- and postkinematic I-type intrusive granitoids (Nironen et al., 2000).

The regional metamorphic grade in the Pohjanmaa Belt increases towards the Vaasa Batholith (Fig. 1), which is indicated by a metamorphic facies series of andalusite-sillimanite; andalusite-staurolitemuscovite schists grading into metatexitic garnetcordierite gneisses, and further into diatexites (Alviola et al., 2001; Lehtonen et al., 2005). The occurrence of orthopyroxene-bearing intermediate metavolcanic intercalations in the garnet-cordierite gneisses adjacent to the Vaasa Batholith indicates that the metamorphic grade was lower granulite facies. The Vaasa Batholith and adjacent diatexites approximately overlap an area called the Bothnian metamorphic core complex by Valtonen (2011) and Valtonen et al. (2011).

Three radiometric age determinations are available from the Vaasa Batholith. A U-Pb monazite age of $1872 \pm 5 \mathrm{Ma}$ for granodiorite of the Vaasa Batholith is reported by Alviola et al. (2001). Sipilä et al. (2008) have dated a granite phase in the Vaasa Batholith; the zircon age estimate is $1878 \pm 4$ $\mathrm{Ma}$, while monazite in the same sample gave a concordant age of $1858 \pm 2 \mathrm{Ma}$. These ages are concordant with the Svecofennian tectono-metamorphic peak in western Finland. The zircon fractions dated in this granite comprise inherited crystals, and indicate a sedimentary source for the Vaasa Batholith (Sipilä et al., 2008).

On aeromagnetic maps, the area of the Vaasa Batholith mostly stands out from the nearby mica schists and mica gneisses of lower intensity. The 
gravimetric data for the study region generally exhibit lower values for the Vaasa Batholith area compared to the mica schists and mica gneisses nearby (Korja et al., 2001; Korhonen et al., 2002).

A major E-W trending fracture zone, also indicated by a gravimetric low, occurs south of the Vaasa Batholith (Fig. 1). It separates regions that have followed different P-T paths (Mäkitie, 2001b); for example, retrograde staurolite and andalusite only occur in migmatitic metapelites on its northern side.

\section{Petrography}

\subsection{Nomenclature}

The rock types in the Vaasa Batholith are named after the following principles. If the rock is relatively uniform, but contains schist relicts and is "igneouslooking" (see Fig. 2), it is named after Le Maitre (1989), although probably formed by partial melting from metasedimentary protolith. With this principle four main granitoid types is distinguished in the Vaasa Batholith (see also Lehtonen et al., 2005; Sipilä et al., 2008): (1) porphyritic granodiorite, (2) even-grained granodiorite, (3) pyroxene- bearing granitoid and (4) granite (Fig. 1).

To get a more exact picture about petrography and chemical composition of these rocks, the orthopyroxene-bearing granitoids are split to orthopyroxene tonalites and to the Raippaluoto orthopyroxene granodiorite, and the granites are divided to granites and to the Punakari granite.

According to Brown (1973), diatexites are rocks where the primary bedding is destroyed. In the present paper, diatexites still contain some ghostlike sedimentary stripes or relicts, and have a weak trend. The studied diatexites are slightly more heterogeneous than the Vaasa Batholith granodiorites. We have settled on these principles, because rather uniform diatexite migmatite and igneouslooking granitoid of the same grain size are texturally often almost similar. Metatexite migmatites are partially melted rocks, where neosome and paleosome can easily be distinguished.

\subsection{Granodiorites}

Porphyritic and even-grained granodiorites, usually greyish in colour, are the two most common rocks in the Vaasa Batholith. They occur in approximately equal areas within the Vaasa Batholith. The

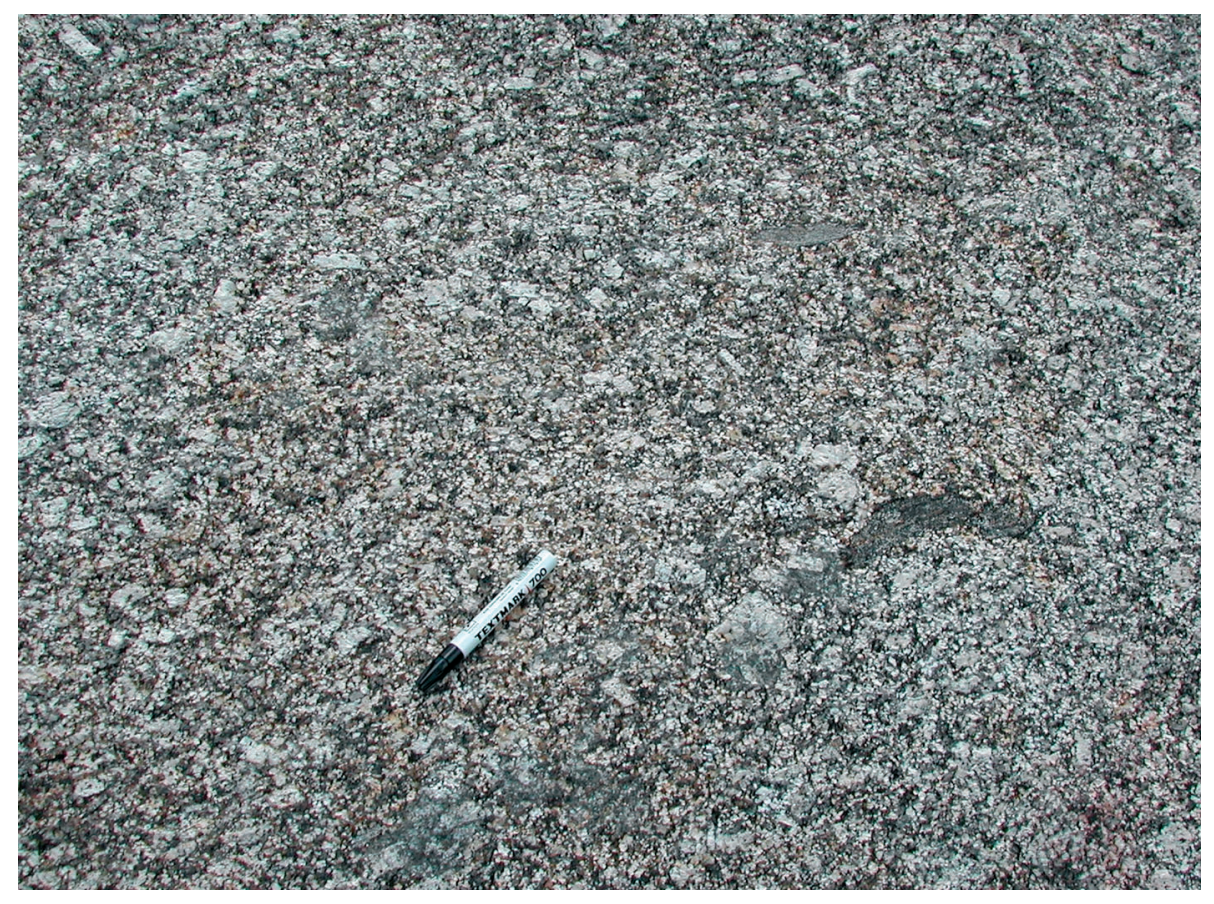

Fig. 2. Granodiorite of the Vaasa Batholith. The rock contains some K-feldspar phenocrysts and small biotite-rich restites. It is texturally intermediate between porphyritic and evengrained type. Ylistaro NE. $x=6998918, y=3285619$. 
granodiorites form large areas but they also occur as irregular bodies between and within other granitoids. Generally they are coarse-grained, slightly inhomogeneous and weakly foliated. Moreover, the granodiorites usually contain indistinct schist and gneiss inclusions, rounded and flattened relicts of calcareous layers or concretions, and restitic biotite-graphite-sulphide-garnet aggregates (see Fig. 2b in Mäkitie, 2001a; Figs. 1214 in Sipilä et al., 2008).

The porphyritic type contains megacrysts (Fig. 3a, see also Fig. 2b in Mäkitie et al., 1999, and Figs. 10 and 11 in Sipilä et al., 2008), locally up to 10 $\mathrm{cm}$ in diameter. Very coarse-grained types occur on the Norrskär Islands in the Gulf of Bothnia and related garnet-rich types about $9 \mathrm{~km} \mathrm{NE}$ of the Vaasa town. Some large feldspar megacrysts are plagioclase, quartz and K-feldspar intergrowths. Typically, the megacrysts are separate from each other. The amount and size of megacrysts in the granodiorite, however, varies; often megacrysts are rare and it is difficult to distinguish between porphyritic and even-grained types texturally (Fig. 2).

The even-grained granodiorites contain more inclusions than the porphyritic types (Fig. 3b, see also Fig. 13 in Sipilä et al., 2008). The portion of these inclusions on outcrop is usually between 0.1 and $4 \%$ in relation to the granodiorite. The inclusions are often slightly elongated and have a parallel common trend. Rarely, some glassy quartz aggregates (3-15 cm in size), small intermediate to mafic metavolcanic fragments and rounded tonalitic inclusions $(0.5-1 \mathrm{~m})$ are found in the granodiorites. The granodiorites do not contain mafic enclaves.

The main minerals in the porphyritic type are K-feldspar (mainly 7-17\%), plagioclase (29-39\%), quartz (27-37\%) and biotite (14-24\%) (Table 1). Common accessory minerals are garnet, retrogressive muscovite, monazite and pyrite. Notably, the granodiorites often contain garnet (mode $<4$ ). Magnetite is very rare and sphene has been never detected. Mineralogically, the even-grained granodiorites resemble the porphyritic ones, but have a lower Kfeldspar mode.

The microscopic texture of the granodiorites is inequigranular and deformed. Biotite has a reddish shade and is strained, with quartz grains exhibiting undulatory extinction. Plagioclase is coarser in grain size than quartz. Crystal faces are locally developed on plagioclase against quartz - a common texture found in granitic rocks that have undergone intense partial melting (Mehnert, 1968; Vernon \& Collins, 1988). Due to the megacrystic K-feldspar crystals of the rocks, point counting results shown in Figure 4 may have notable error limits.

\subsection{Pyroxene granitoid}

Orthopyroxene-bearing tonalite occurs as small irregular bodies, $0.5-2 \mathrm{~km}^{2}$ by extent, mostly near the town of Kauhava and in the parish of Vähäkyrö (Fig. 1). The rock is weakly foliate and its fresh surface is greenish dark in colour (Mäkitie, 2001a; Fig. 2c). The weathered surface of the rock is slightly rusty (Fig. 3c). Supracrustal inclusions are relatively rare in these tonalites compared to the porphyritic and even-grained granodiorites. The grain size in the orthopyroxene tonalite is 1 to $7 \mathrm{~mm}$. Locally, the dark colour of the tonalite changes to light-pink without textural transform.

The main minerals in the tonalite are plagioclase, quartz and biotite (Table 1). Orthopyroxene content ranges from 1 to $12 \%$. Rare K-feldspar megacrysts (up to $2.5 \mathrm{~cm}$ in size) occur in the rock of the Kauhava area. In places garnet coexists with orthopyroxene. In some tonalites, retrograde amphibole crystals occasionally form rims around orthopyroxene. Monazite is an accessory mineral in these rocks.

An orthopyroxene-bearing granodiorite about two square kilometres in extent occurs near the Raippaluoto village, $15 \mathrm{~km}$ north of the town of Vaasa (Fig. 1). The rock is porphyritic, weakly deformed and contains some schist relicts. Mineralogically it resembles the aforementioned tonalites at Kauhava and Vähäkyrö, but with more K-feldspar phenocrysts. The granodiorite contains some aplitic and pegmatitic patches.

\subsection{Granite}

There are three larger granite areas (50-200 $\mathrm{km}^{2}$ ) within the Vaasa Batholith; in the Vöyri, Kalotfjär- 

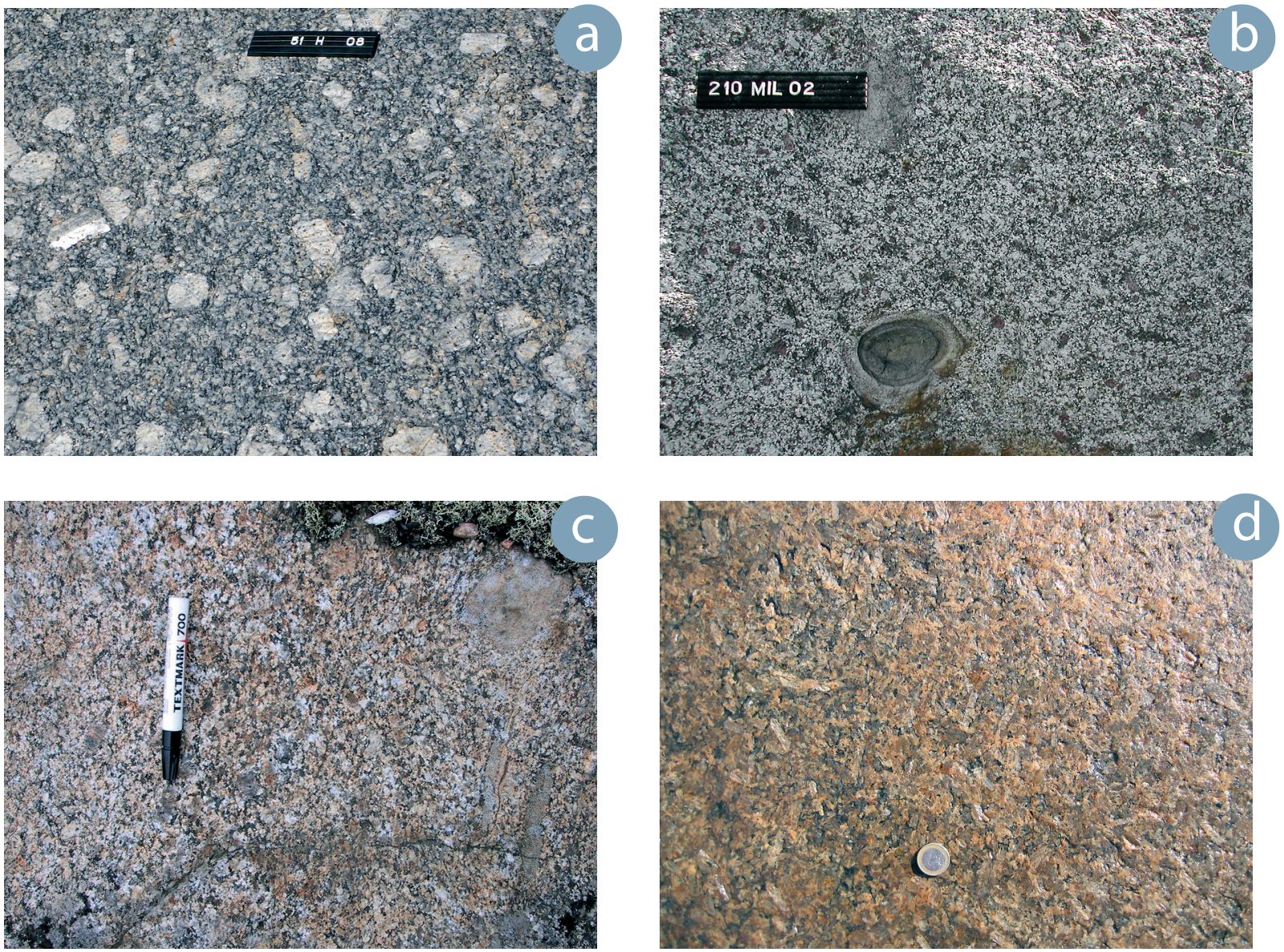

Fig. 3. Granitoids of the Vaasa Batholith. (a) Megacrystic granodiorite, which has very coarse-grained K-feldspar phenocrysts. Norrskär Islands, $x=6978090, y=1540500$. (b) Even-grained granodiorite, which contains supracrustal Carich inclusion and psammitic relict (near number plate). Ylistaro N, x=6996860, y=3273845. (c) Orthopyroxene-bearing tonalite. Note the schist relicts on the right. Vähäkyrö, $x=7004070, y=3251430$. (d) Punakari granite, which has euhedral K-feldspar phenocrysts. Trollbärsskäret, $x=7040220, y=3231560$. Number plate $12 \mathrm{~cm}$, coin $2.5 \mathrm{~cm}$ in size.

Table 1. Average modal composition of granitoid types in the Vaasa Batholith, and nearby diatexites and metatexites.

\begin{tabular}{|c|c|c|c|c|c|c|c|c|c|c|c|c|}
\hline \multirow[b]{2}{*}{$n=$} & \multicolumn{2}{|c|}{$\begin{array}{l}\text { Porphyritic } \\
\text { granodiorite }\end{array}$} & \multicolumn{2}{|c|}{$\begin{array}{l}\text { Even-grained } \\
\text { granodiorite }\end{array}$} & \multicolumn{2}{|c|}{$\begin{array}{l}\text { Pyroxene } \\
\text { granitoid }\end{array}$} & \multicolumn{2}{|c|}{ Granite } & \multicolumn{2}{|c|}{ Diatexite } & \multicolumn{2}{|c|}{ Metatexite } \\
\hline & 9 & & 17 & & 8 & & 16 & & 10 & & 7 & \\
\hline Plagioclase & 34.2 & $(23.0-45.1)$ & 38.2 & $(24.0-49.8)$ & 38.5 & $(25.0-54.0)$ & 23.8 & $(13.8-30.6)$ & 28.2 & (16.4-51.4) & 27.9 & $(9.6-34.8)$ \\
\hline Quartz & 32.4 & $(20.8-41.6)$ & 33.9 & $(27.2-46.0)$ & 28.6 & $(19.8-39.4)$ & 30.0 & $(17.4-44.4)$ & 23.7 & $(9.6-38.7)$ & 25.4 & (14.1-45.5) \\
\hline K-feldspar & 12.3 & $(0.2-28.0)$ & 7.8 & $(0.4-20.6)$ & 4.7 & $(0-25.6)$ & 35.1 & $(18.0-53.2)$ & 14.3 & $(3.8-27.2)$ & 4.8 & $(0-14.6)$ \\
\hline Biotite & 18.9 & $(8.5-32.0)$ & 17.0 & $(6.7-27.0)$ & 19.8 & $(10.4-33.4)$ & 9.2 & $(0.6-22.0)$ & 25.3 & $(8.7-35.0)$ & 33.1 & $(16.5-47.4)$ \\
\hline Orthopyroxene & - & & - & & 5.4 & $(1.2-12.0)$ & - & & - & & - & \\
\hline Garnet & 0.9 & & 1.1 & & 0.4 & & 0.5 & & 4.0 & & 4.1 & \\
\hline Cordierite & - & & 0.1 & & - & & - & & 3.1 & & 2.9 & \\
\hline Muscovite & 0.6 & & 1.0 & & - & & 0.6 & & - & & - & \\
\hline Others & 0.7 & & 0.9 & & 2.6 & & 0.8 & & 1.4 & & 1.8 & \\
\hline Total & 100.0 & & 100.0 & & 100.0 & & 100.0 & & 100.0 & & 100.0 & \\
\hline
\end{tabular}


den and Punakari areas (Fig. 1). The maps of Björk et al. (2007) and Sipilä et al. (2008) show the extent of these granitoids more accurately. The Vöyri granite is coarse grained and locally porphyritic in texture (Sipilä et al., 2008; Fig. 15), and generally more homogeneous in contrast to the granodiorites. It has some schist relicts and $\mathrm{Ca}$-concretion-like inclusions, and grades to the granodiorites nearby. The granite in the Kalotfjärden area resembles that at Vöyri, but it is poorly exposed. A rounded aeromagnetic area with low intensity seems to limit the extent of the Kalotfjärden granite. Both of these lastmentioned granites contain 10-20\% biotite. Garnet is rare.

The Punakari granite usually contains Kfeldspar megacrysts that are nearly euhedral (Fig. $3 \mathrm{~d}$ ), which trend locally is due to magmatic flow. The granite has a slight reddish shade compared to the nearby granodiorites but there are also grey coloured granites. Garnet is much more common in the Punakari granite than in the granite at Vöyri, but schist relicts and $\mathrm{Ca}$-concretions are practically absent in the Punakari granite. Garnet is often concentrated in weakly visible feldspar- and quartzrich patches. The granite contains about $10 \%$ biotite. Muscovite (locally up to $2 \%$ ) and monazite are detected in the rock as accessory minerals. As a curiosity, the Punakari granite has heterogeneous zircon population (Sipilä et al., 2008).

\subsection{Diatexite migmatite}

The diatexite migmatites are either located at the margins of the Vaasa Batholith or they form individual, elongate areas $\left(0.1-4 \mathrm{~km}^{3}\right)$ within it. Most often they form 50-500 m wide gradational zones between the Vaasa granodiorites and the metatexitic mica gneisses of the Pohjanmaa Belt.

The diatexites contain melted schist relicts $(0.01$ $-10 \mathrm{~m}^{2}$ ), and can be described as ghost-like nebulitic migmatites with abundant leucosome. Locally, the relicts include evidence of migmatization older than the crystallization of the surrounding magma ( $\mathrm{Si}$ pilä et al., 2008; Fig. 14). Specifically, the metapelitic schist relicts have irregular and ragged margins while the psammitic and intermediate relicts have rather

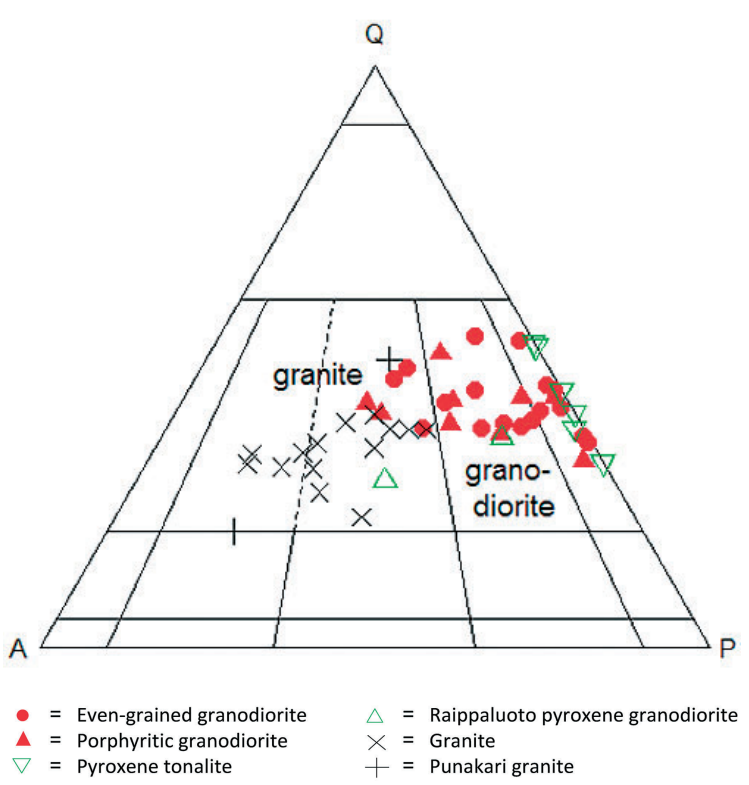

Fig. 4. Classification diagram of Streckeisen (1976) for the granitoids of the Vaasa Batholith. Measurements are made by point counting ( 600 points per thin section).

sharp margins and are often subrounded. However, in many instances, the metapelitic structures are almost obliterated resulting in diatexite (Fig. 5a). Layering in a part of the outcrop may be migmatitic while in another part is intensely homogenized due to melting.

Detailed textural descriptions of outcrops that are (1) transitional from metatexite to diatexite migmatite and (2) uniform diatexite migmatite located at the margin of Vaasa Batholith are given in Sawyer (2008, Figs. D45 and D61). Photographs of diatexites surrounding the Vaasa Batholith and located against metatexites of the Pohjanmaa Belt are also presented by Mäkitie (2001a, Figs. 2d-2f and 4).

The main minerals of the diatexites are $\mathrm{K}$ feldspar (mainly 9-19\%), plagioclase (23-33\%), quartz (19-29\%), biotite (20-30\%) and garnet (1-7\%) (Table 1). Accessory minerals are cordierite, monazite, sillimanite (usually as fibrolite in cordierite), retrogressive andalusite, muscovite, opaque and various pinitized pseudomorphs. The quartz crystals may rarely contain turbid cores surrounded by fresh quartz (Fig. 5b); an obvious textural relict of partial melting. 


\subsection{Metatexite migmatite}

The metatexites near the aforementioned diatexites are migmatitic porphyroblastic garnet-cordierite mica gneisses, in which the amount of neosome varies (e.g. Alviola et al., 2001; Lehtonen et al., 2005; Sipilä et al., 2008). They also comprise psammitic intercalations. The proportion of granitic leucosome increases in the metatexites towards the diatexites and towards the Vaasa Batholith. Finally, the supracrustal features in the metatexite disappear and the rock grades to diatexite (Fig. 5a).

The main mineralogy of the metatexite migmatites is plagioclase, quartz, biotite, K-feldspar, garnet and cordierite (Table 1). Garnet occurs both in the paleosome and in the granitic neosome of the mica gneisses. Accessory minerals include, for example, hercynite, monazite and sillimanite. Locally the mica gneisses contain graphite and sulphides.

\subsection{Other rocks}

The Vaasa Batholith contains some cross-cutting aplite and pegmatite dykes. In the parish of Vöyri, east of Vaasa town, there are migmatitic metaarkoses forming an area of $3 \mathrm{~km}^{2}$ (Lehtonen et al., 2005). A relative large $\left(25 \mathrm{~km}^{2}\right)$ monzogabbroic intrusion showing a strong magnetic anomaly occurs in the archipelago west of Vaasa and two small ultramafic bodies are reported in the northern part of the Vaasa Batholith (Isohanni, 1985; Lehtonen et al., 2005). Topaz-bearing $\sim 1.80 \mathrm{Ga}$ rare-metal granitic pegmatites occur at the SE margin of the Vaasa Batholith, but are predominant in the diatexite migmatites (Alviola et al., 2001). Near the town of Vaasa, there is a feldspar porphyry dyke with an estimated age of $\sim 1.80 \mathrm{Ga}$ (Lehtonen et al., 2005).

\subsection{Structural features}

Hundreds of structural measurements are available for the Vaasa Batholith and nearby migmatites (see the GTY database of the Geological Survey of Finland). They show that the lineations and fold axes in the Vaasa Batholith and nearby migmatites have a dominant, east-west trending direction. The dips of lineations within the Vaasa Batholith plunge to the east. On the other hand, the lineations in metatexites located east of the Vaasa Batholith dip towards the west. This indicates that a depression zone is located approximately where there are diatexites (see also Laitakari, 1942). Moreover, the lineations are perpendicular to the N-S trending strike in the Pohjanmaa Belt metatexites in the aforementioned area.

The strikes of foliations in the Vaasa Batholith rocks mostly trend approximately east-west or north-
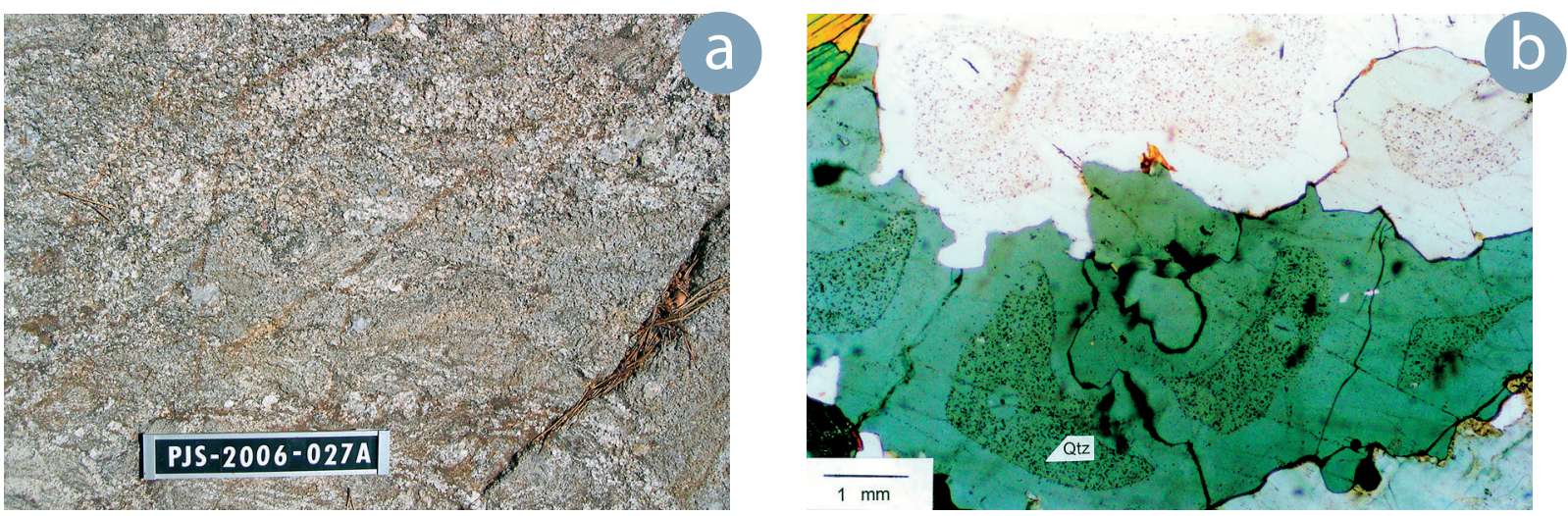

Fig. 5. Textures in diatexite migmatites surrounding the Vaasa Batholith. (a) Close-up photo of ghost-like supracrustal relict in diatexite. Lapua $\mathrm{N}, \mathrm{x}=6990185, \mathrm{y}=3293057$. (b) Microphotograph of diatexite. The epitaxial texture represents quartz precipitation on older turbid quartz cores that have undergone melting. Crossed nicols. Vähäkyrö NW, $x=7007890$, $\mathrm{y}=3250380$. Number plate $12 \mathrm{~cm}$. 
south. The aforementioned north-south trend is, however, perpendicular to the east-west trend of foliations, which characterize the migmatites on the southern side of the Vaasa Batholith. The Punakari granite contains in its north-western part gently dipping planar structures.

\section{Chemical composition}

\subsection{Sampling and analytical procedures}

The chemical composition of the Vaasa Batholith, and the diatexite and metatexite migmatites nearby was studied with 194 whole rock analyses. Analysed rocks are macroscopically divided into the following classes (amount of analyses in parenthesis): porphyritic granodiorite (45), even-grained granodiorite (60), pyroxene tonalite (8), Raippaluoto pyroxene granodiorite (3), granite (12), Punakari granite (3), diatexite (25) and metatexite (38). The samples of diatexite and metatexite were taken from locations no more than $10 \mathrm{~km}$ from the Vaasa Batholith. The analysed rock samples are equally spread out in the study area.

Most of the chemical analyses are from the Rock Geochemical Database of Finland (see Rasilainen et al., 2007, see also www.gtk.fi). Analyses presented by Mäkitie et al. (1999), Mäkitie (2001a), Lehtonen et al. (2005) and Sipilä et al. (2008) were also used. Only five chemical analyses represent unpublished data.

The main chemical elements in the rock samples were determined by XRF as were $\mathrm{Ba}, \mathrm{Cr}, \mathrm{F}, \mathrm{Ga}, \mathrm{Nb}$, $\mathrm{Ni}, \mathrm{Rb}, \mathrm{Sr}, \mathrm{U}, \mathrm{V}, \mathrm{Y}, \mathrm{Zn}$ and $\mathrm{Zr}$. The lanthanides and some elements such as $\mathrm{Co}$, Ta and Th were analysed by ICP-MS and Li and Sc contents were obtained by ICP-AES. Most of the analyses were made at the Geological Survey of Finland. Detailed descriptions of the applied analytical methods are given in Rasilainen et al. (2007).

The analytical data are large and collected from many references. Therefore, the following principles are used in the calculations (see Table 2). If less than $25 \%$ of the available element concentrations - in a single rock type - were below the detection limit, the arithmetic mean was calculated using half of the detection limit for those minority cases. If over 25 per cent of the available element analyses were below detection limits, no mean values are presented, but some comments on the concentrations detected are given. Representative chemical analyses of granitoids in the Vaasa Batholith, and nearby diatexites and metatexites are in Appendix 1.

The chemical compositions of minerals in the studied rocks were determined by using a Cameca CAMEBAX SX50 electron probe microanalyzer at the Geological Survey of Finland. The central areas of fresh and relative large crystals were analysed. The amount of microprobe analyses is small, and, thus, no variations are given (Table 3 ).

\subsection{Major and minor elements}

All studied rocks are peraluminous in composition; diatexite migmatites have the highest average A/ CNK (1.23) (Table 2) while the orthopyroxenebearing granitoids are less peraluminous (1.031.07). In terms of the major chemical elements, most of the studied granitoid samples classify as granodiorite in the TAS diagram of Cox et al. (1979) and in the $\mathrm{R}_{1}-\mathrm{R}_{2}$ diagram of De la Roche et al. (1980) (Figs. 6a and 6b). In these diagrams the tonalites and granites separate, but the Raippaluoto pyroxene granodiorites remain in the granodiorite field. On the Q' vs. ANOR diagram of Streckeisen and Le Maitre (1979), the granodiorite samples are mainly distributed between the adamellite and granodiorite fields (Fig. 6c), while the granite samples plot in the adamellite field, and the Punkari granite samples in the alkali feldspar granite field. The relatively high (17-19\%) mode of biotite in granodiorites may have increased the normative $\mathrm{Or}$ value, because many granodiorites occur in the granite field instead of the granodiorite field of the diagram. All granitoids, except for some orthopyroxene-bearing tonalites, contain normative corundum.

Harker variation diagrams for selected chemical elements are shown in Figures $7 \mathrm{a}-7 \mathrm{f}$. These diagrams show that most of the granitoids in the Vaasa 

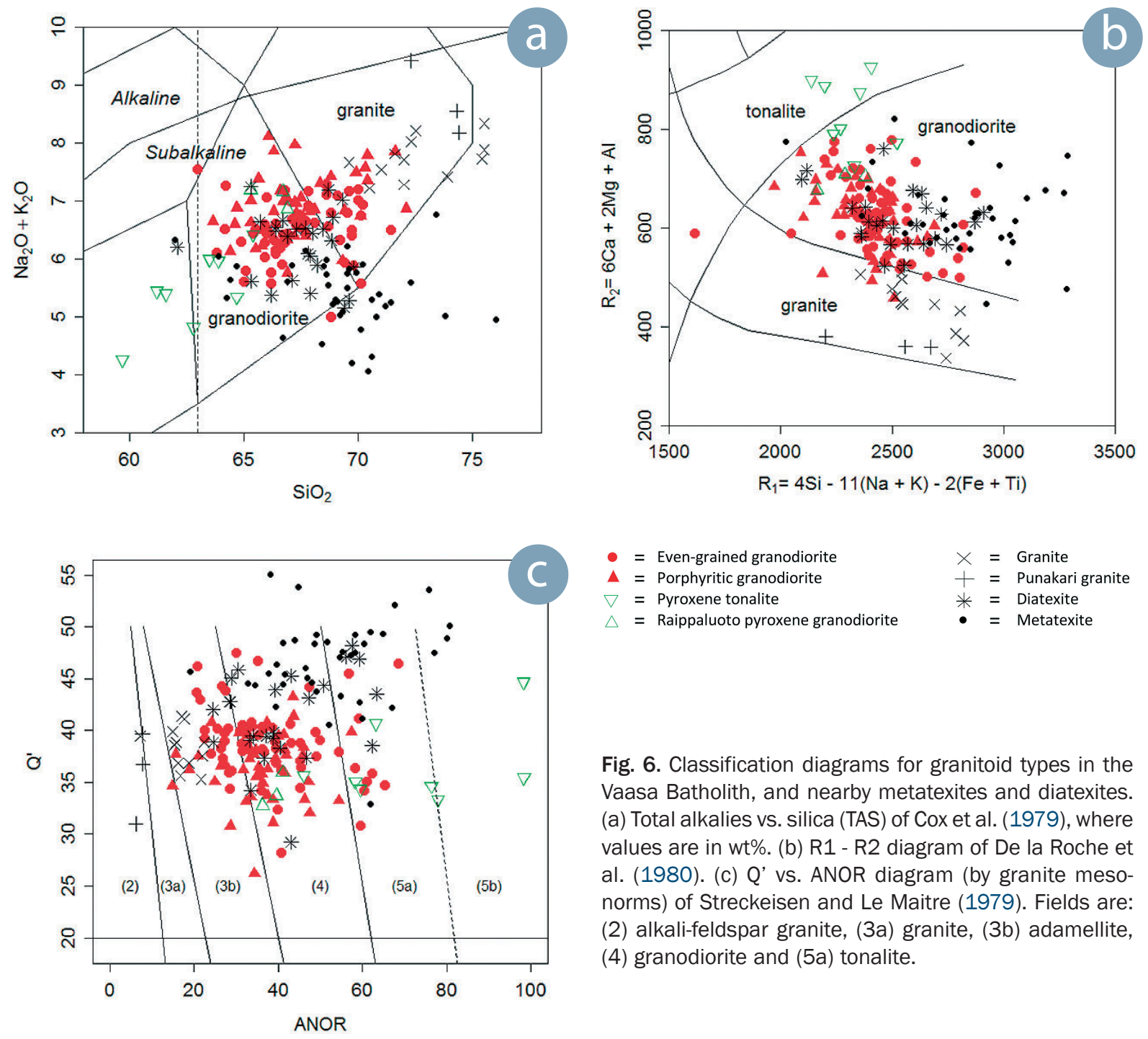

$\begin{aligned} \bullet & =\text { Even-grained granodiorite } \\ \Delta & =\text { Porphyritic granodiorite } \\ \nabla & =\text { Pyroxene tonalite } \\ \Delta & =\text { Raippaluoto pyroxene granodiorite }\end{aligned}$

$$
\begin{aligned}
x & =\text { Granite } \\
+ & =\text { Punakari granite } \\
* & =\text { Diatexite } \\
\bullet & =\text { Metatexite }
\end{aligned}
$$

Fig. 6. Classification diagrams for granitoid types in the Vaasa Batholith, and nearby metatexites and diatexites. (a) Total alkalies vs. silica (TAS) of Cox et al. (1979), where values are in wt\%. (b) R1 - R2 diagram of De la Roche et al. (1980). (c) Q' vs. ANOR diagram (by granite mesonorms) of Streckeisen and Le Maitre (1979). Fields are: (2) alkali-feldspar granite, (3a) granite, (3b) adamellite, (4) granodiorite and (5a) tonalite.

Batholith plot along a trend. However, in part, the metatexites plot off the trend or cut it.

Granodiorite, the main rock type in the Vaasa Batholith, has relatively high $\mathrm{FeOt}+\mathrm{MgO}$ values (6.5-6.8 wt\%) overall. Its $\mathrm{TiO}_{2}, \mathrm{Al}_{2} \mathrm{O}_{3}, \mathrm{FeOt}, \mathrm{MgO}$ and $\mathrm{CaO}$ contents often overlap with those of the diatexites (Figs. 7a-7e). Sampling was slightly focused on the homogenous parts of the granodiorites resulting in chemical data are generally rather too granitic. The $\mathrm{Fe}-, \mathrm{Mg}-$, $\mathrm{Ca}$-rich relicts in the rocks are absent from the results.

The orthopyroxene-bearing tonalites have the lowest mean $\mathrm{SiO}_{2}$ value $(62.8 \mathrm{wt} \%)$ but highest $\mathrm{TiO}_{2}$ (1.10 wt \%), FeOt (7.42 wt \%), $\mathrm{MgO}(2.72 \mathrm{wt} \%)$,

$\mathrm{CaO}$ (3.71 wt\%), Ba (732 ppm) and $\mathrm{Ni}$ (72 ppm) (Table 2). The pyroxene granodiorite at Raippaluoto has higher Si and $\mathrm{K}$ contents, but lower Ti, Fe, Mg and $\mathrm{Ca}$ contents than the tonalite type. It partly resembles the granodiorites in composition. Elevated $\mathrm{Cr}$ contents (up to $141 \mathrm{ppm}$ ) are detected in the rock. As a curiosity, the pyroxene tonalites may have slightly elevated fluorine and lithium contents; the only sample analysed in terms of these elements contained $0.23 \mathrm{wt} \%(\mathrm{~F})$ and $42 \mathrm{ppm}$ (Li) (see Rasilainen et al., 2007, analysis 93002922).

The granites have the highest $\mathrm{SiO}_{2}$ and $\mathrm{K}_{2} \mathrm{O}$ contents and the lowest Ti, Ca, FeOt, $\mathrm{MgO}, \mathrm{Sr}, \mathrm{Zn}$ and $\mathrm{Zr}$ concentrations compared to the other 
Table 2. Average chemical composition of granitoids in the Vaasa Batholith, and nearby diatexites and metaxites. The composition is shown as an arithmetic mean. Locally, the amount $(n)$ of analyses is referred in square brackets.

\begin{tabular}{|c|c|c|c|c|c|c|c|c|c|c|c|}
\hline \multirow{3}{*}{$\begin{array}{l}\mathrm{n}= \\
\mathrm{SiO}, \mathrm{wt} \%\end{array}$} & \multirow{2}{*}{\multicolumn{2}{|c|}{$\begin{array}{c}\text { Porphyritic } \\
\text { granodiorite } \\
45\end{array}$}} & \multicolumn{3}{|c|}{$\begin{array}{l}\text { Even-grained } \\
\text { granodiorite }\end{array}$} & & \multicolumn{2}{|l|}{$\begin{array}{r}\text { Pyroxene } \\
\text { tonalite }\end{array}$} & \multicolumn{2}{|c|}{$\begin{array}{c}\text { Raippaluoto } \\
\text { pyroxene } \\
\text { granodiorite }\end{array}$} & \\
\hline & & & & 60 & & & 8 & & & 3 & \\
\hline & 67.4 & & $(63.7-72.1)$ & 67.4 & & $(63.0-71.4)$ & 62.8 & & $(59.7-66.9)$ & 66.3 & $(65.3-66.9)$ \\
\hline $\mathrm{TiO}_{2}^{2}$ & 0.72 & & $(0.19-1.07)$ & 0.66 & & $(0.38-1.01)$ & 1.10 & & $(0.76-1.34)$ & 0.80 & $(0.76-0.84)$ \\
\hline $\mathrm{Al}_{2} \mathrm{O}_{3}$ & 15.0 & & (13.9-16.3) & 14.9 & & $(13.5-17.1)$ & 15.4 & & $(14.3-16.6)$ & 14.5 & (14.3-14.8) \\
\hline $\mathrm{FeOt}^{2}$ & 4.73 & & $(2.07-7.07)$ & 4.77 & & $(2.69-7.59)$ & 7.42 & & $(4.45-10.58)$ & 4.77 & $(4.45-5.38)$ \\
\hline $\mathrm{MnO}$ & 0.05 & & (0.03-0.09) & 0,06 & & $(0.02-0.14)$ & 0.09 & & $(0.05-0.12)$ & 0.05 & $(0.05-0.06)$ \\
\hline $\mathrm{MgO}$ & 1.78 & & $(0.79-3.22)$ & 1.98 & & $(1.33-3.10)$ & 2.72 & & $(2.15-4.03)$ & 2.48 & $(2.15-2.68)$ \\
\hline $\mathrm{CaO}$ & 2.25 & & $(1.31-3.23)$ & 2.14 & & $(1.12-3.57)$ & 3.71 & & $(2.61-4.45)$ & 2.69 & (2.61-2.76) \\
\hline $\mathrm{Na}_{2} \mathrm{O}$ & 2.29 & & $(1.89-3.94)$ & 3.00 & & $(1.20-5.08)$ & 3.05 & & $(2.47-3.66)$ & 2.74 & $(2.70-2.78)$ \\
\hline $\mathrm{K}_{2} \mathrm{O}$ & 3.89 & & $(2.46-5.42)$ & 3.52 & & $(1.99-4.95)$ & 2.40 & & $(1.16-4.45)$ & 4.33 & $(4.16-4.45)$ \\
\hline $\mathrm{P}_{2}^{2} \mathrm{O}_{5}$ & 0.18 & & $(0.03-0.33)$ & 0.19 & & $(0.05-0.38)$ & 0.27 & & $(0.15-0.38)$ & 0.16 & $(0.16-0.17)$ \\
\hline Total & 98.29 & & & 98.62 & & & 98.96 & & & 98.82 & \\
\hline $\mathrm{A} / \mathrm{CNK}$ & 1.13 & & & 1.18 & & & 1.07 & & & 1.03 & \\
\hline $\mathrm{Rb} / \mathrm{Sr}$ & 0.92 & & & 0.78 & & & 0.35 & & & 1.09 & \\
\hline $\mathrm{Ba} \quad \mathrm{ppm}$ & 648 & & $(171-1352)$ & 598 & & $(106-1358)$ & 732 & & $(200-1006)$ & 637 & $(570-754)$ \\
\hline Co & 13 & [21] & $(7-16)$ & 13 & [27] & $(6-22)$ & 17 & [3] & $(15-18)$ & n.a. & \\
\hline $\mathrm{Cr}$ & $70 *$ & & (b.d.l.-155) & 78 & & $(28-184)$ & 88 & [6] & $(81-97)$ & 141 & $(89-168)$ \\
\hline$F \quad$ (in wt\%) & 0.11 & [19] & $(0.07-0.18)$ & 0.10 & {$[25]$} & $(0.06-0.24)$ & 0.23 & [1] & & n.a. & \\
\hline $\mathrm{Ga}$ & 26 & [37] & $(20-30)$ & 25 & [51] & $(21-35)$ & 25 & [5] & $(19-28)$ & 21 & $(20-23)$ \\
\hline $\mathrm{Hf}$ & 5.6 & [20] & $(3.4-7.8)$ & 4.6 & [25] & $(3.5-5.7)$ & 6.1 & [3] & $(4.9-6.9)$ & n.a. & \\
\hline $\mathrm{Li}$ & 31 & [20] & $(17-59)$ & 33 & [27] & $(19-51)$ & 42 & [1] & & n.a. & \\
\hline $\mathrm{Nb}$ & $17^{*}$ & [41] & (b.d.I.-25) & 15 & [57] & $(8-23)$ & 14 & [3] & $(13.6-14.4)$ & 12 & $(12-13)$ \\
\hline $\mathrm{Ni}$ & $30 *$ & [43] & (b.d.I.-63) & $31 *$ & & (b.d.I.-70) & 72 & [6] & $(20-286)$ & 46 & $(35-54)$ \\
\hline $\mathrm{Rb}$ & 180 & & $(98-240)$ & 162 & & $(64-236)$ & $77^{*}$ & {$[8]$} & (b.d.l.-205) & 203 & (198-205) \\
\hline $\mathrm{S}$ & $978 *$ & {$[42]$} & (b.d.l.-2518) & $1024 *$ & {$[58]$} & (b.d.l-2815) & 1018 & [6] & $(252-1950)$ & 500 & (252-968) \\
\hline Sc & $12.9 *$ & [37] & (b.d.l.-22.4) & 13.4 & [52] & $(5.4-26.7)$ & 21.0 & [3] & $(19.1-22.2)$ & n.a. & \\
\hline $\mathrm{Sr}$ & 195 & & $(116-275)$ & 208 & & (98-309) & 218 & [8] & $(170-272)$ & 186 & (180-197) \\
\hline $\mathrm{Ta}$ & 1.0 & [21] & $(0.5-2.0)$ & 1.0 & [27] & $(0.43-1.87)$ & 0.8 & [3] & $(0.7-1.0)$ & 0.7 & (0.53-0.72) \\
\hline Th & 17.1 & [39] & $(3.7-40.6)$ & 15.2 & & $(2.4-36.6)$ & 8.0 & [6] & $(2.0-15.0)$ & 15 & $(8.8-18.6)$ \\
\hline$U$ & $1.9 *$ & [37] & (b.d.l.-4.4) & $2.5^{*}$ & [55] & (b.d.I.-5.4) & 3.5 & [6] & $(0.6-8.0)$ & 2.4 & $(1.41-3.61)$ \\
\hline V & $89 *$ & {$[40]$} & (b.d.I.-143) & 95 & [55] & $(46-142)$ & 133 & [6] & $(116-154)$ & 92 & $(80-104)$ \\
\hline$Y$ & $23^{*}$ & {$[40]$} & (b.d.l.-61.1) & 22.3 & [55] & $(6.7-53.3)$ & 21.0 & & $(10.0-40.7)$ & 18 & $(12.0-21.3)$ \\
\hline $\mathrm{Zn}$ & 101 & & $(56-232)$ & 96 & & $(56-135)$ & 119 & [6] & $(90-140)$ & 74 & $(66-87)$ \\
\hline $\mathrm{Zr}$ & 222 & {$[44]$} & $(96-357)$ & 203 & [58] & $(115-368)$ & 248 & & $(160-287)$ & 268 & $(258-278)$ \\
\hline $\mathrm{n}=$ & 37 & & & 52 & & & 3 & & & & \\
\hline $\mathrm{Ce}$ & 92.4 & & $(29.5-177)$ & 85.1 & & (30.7-192) & 91.7 & & $(71.4-114)$ & 81.6 & (79.9-84.5) \\
\hline Dy & 4.45 & & $(1.49-9.94)$ & 4.25 & & $(1.99-8.99)$ & 0.42 & & $(2.57-7.13)$ & 3.35 & $(2.54-3.78)$ \\
\hline $\mathrm{Er}$ & 2.15 & & $(0.52-5.70)$ & 2.06 & & $(0.37-5.14)$ & 2.25 & & $(0.97-3.91)$ & 1.64 & $(1.13-2.01)$ \\
\hline Eu & 1.03 & & $(0.70-1.43)$ & 1.03 & & $(0.58-1.46)$ & 1.50 & & $(1.47-1.53)$ & 0.94 & $(0.85-1.08)$ \\
\hline Gd & 0.79 & & $(2.86-12.1)$ & 6.51 & & $(3.47-13.0)$ & 6.72 & & $(6.14-7.88)$ & 5.15 & $(4.18-5.87)$ \\
\hline Ho & 0.81 & & $(0.23-2.06)$ & 0.77 & & $(0.21-1.73)$ & 0.80 & & $(0.42-1.35)$ & 0.59 & $(0.41-0.70)$ \\
\hline La & 44.7 & & $(13.5-90.1)$ & 40.7 & & $(15.4-89.8)$ & 47.0 & & $(36.1-58.5)$ & 40.9 & (39.4-41.7) \\
\hline Lu & $0.26 *$ & & (b.d.l.-0.62) & $0.27 *$ & & (b.d.l.-0.66) & 0.33 & & $(0.13-0.52)$ & 0.20 & $(0.12-0.24)$ \\
\hline $\mathrm{Nd}$ & 0.7 & & $(16.2-68.2)$ & 38.0 & & $(13.7-88.7)$ & 36.8 & & $(32.5-48.3)$ & 33.7 & $(32.5-34.6)$ \\
\hline $\operatorname{Pr}$ & 10.72 & & $(3.68-18.7)$ & 9.86 & & $(3.68-22.4)$ & 10.84 & & $(9.01-13.1)$ & 9.15 & $(8.78-9.50)$ \\
\hline Sm & 7.50 & & $(4.33-13.5)$ & 7.06 & & $(3.18-15.0)$ & 7.21 & & $(6.72-7.90)$ & 5.47 & $(5.02-5.81)$ \\
\hline $\mathrm{Tb}$ & 0.91 & & $(0.39-1.69)$ & 0.87 & & $(0.49-1.71)$ & 0.88 & & $(0.65-1.29)$ & 0.66 & $(0.53-0.72)$ \\
\hline $\mathrm{Tm}$ & $0.29 *$ & & (b.d.l.-0.69) & 0.29 & & (b.d.I.-0.71) & 0.30 & & $(0.14-0.50)$ & 0.22 & $(0.13-0.27)$ \\
\hline $\mathrm{Yb}$ & $1.88 *$ & [34] & (b.d.l.-4.40) & 1.76 & {$[40]$} & (b.d.I.-4.07) & 2.13 & & $(0.95-3.36)$ & n.a. & \\
\hline$(\mathrm{La} / \mathrm{Yb}) \mathrm{N}$ & 16.04 & & & 15.58 & & & 14.91 & & & n.a. & \\
\hline$(\mathrm{La} / \mathrm{Sm}) \mathrm{N}$ & 3.75 & & & 3.63 & & & 4.10 & & & 4.70 & \\
\hline $\begin{array}{l}\text { Eu/Eu* } \\
\text { (after Boynt }\end{array}$ & $\begin{array}{r}0.44 \\
\text { ton, } 1984)\end{array}$ & & & 0.47 & & & 0.66 & & & 0.54 & \\
\hline
\end{tabular}

* $\quad=\quad<25 \%$ of available determinations are below detection limit (b.d.I.); mean is calculated using half of the detection limits

b.d.I. $=>25 \%$ of available determinations are below detection limit

n.a. $=$ not analysed 
Table 2. Continues ...

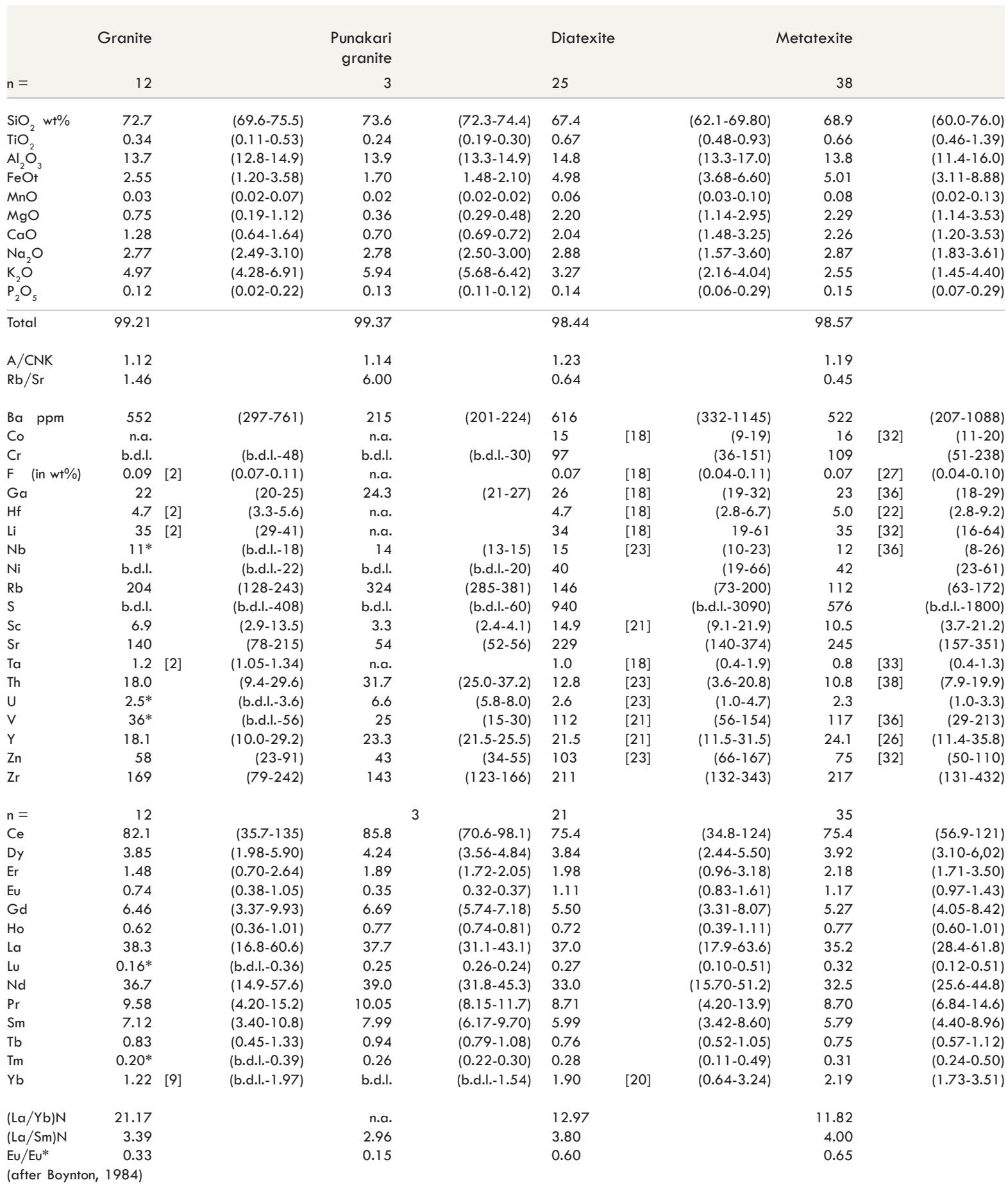

\footnotetext{
* $\quad=\quad<25 \%$ of available determinations are below detection limit (b.d.I.); mean is calculated using half of the detection limits b.d.I. $=>25 \%$ of available determinations are below detection limit

n.a. $=$ not analysed
} 

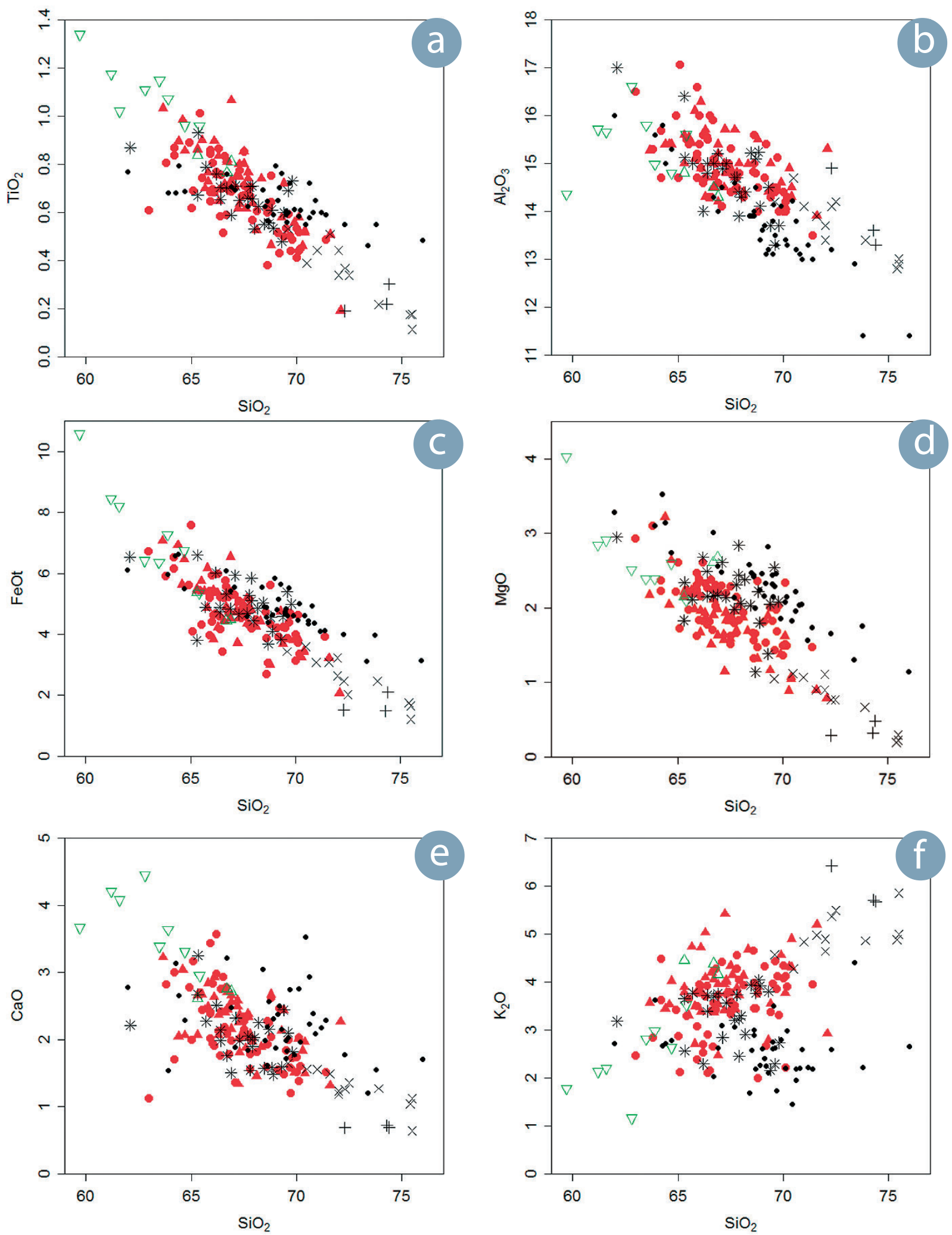

- = Even-grained granodiorite $\nabla=$ Pyroxene tonalite

$X=$ Granite

* = Diatexite

$\Delta=$ Porphyritic granodiorite

$\triangle=$ Raippaluoto pyroxene granodiorite

$+=$ Punakari granite

- $=$ Metatexite

Fig. 7. Harker diagrams for granitoid types in the Vaasa Batholith, and diatexites and metatexites nearby. Values are in wt\%. 
granitoids (Table 2). Apart from the orthopyroxene tonalite, the amount of $\mathrm{K}$ (and $\mathrm{Rb}$ ) increases from the metatexites to the diatexites, and further from the granodiorites to the granites (Table 2). At the same time $\mathrm{Fe}, \mathrm{Mg}, \mathrm{Ni}, \mathrm{Cr}, \mathrm{V}$ contents slightly decrease in the same rocks. The Punakari granite has the highest $\mathrm{K}$ content and $\mathrm{Rb} / \mathrm{Ba}$ (Table 2). It also contains much less sulphur than the other granitoids. The granite phases of the Vaasa Batholith have lower $\mathrm{Mg}$ \# ( $\mathrm{Mg}$ number, molar $100^{*} \mathrm{Mg} /$ $(\mathrm{Mg}+\mathrm{Fe}))(-20)$ in biotite compared to the $\mathrm{Mg}$ number of biotite of the Vaasa Batholith granodiorites.

The $\mathrm{TiO}_{2}, \mathrm{FeOt}, \mathrm{MgO}, \mathrm{Na}_{2} \mathrm{O}$ concentrations in diatexites resemble those detected in the metatexites. However, in comparison to the diatexites, the metatexites have slightly higher calcium content but lower aluminium and potassium contents (Table 2).

On average, the metatexites are not very rich in $\mathrm{Al}_{2} \mathrm{O}_{3}(\leq 14 \mathrm{wt} \%)$, because they also comprise psammitic portions. On Harker diagrams, the metatexites usually have slightly higher $\mathrm{TiO}_{2}, \mathrm{FeOt}$, $\mathrm{MgO}$ and $\mathrm{CaO}$ - when plotted against $\mathrm{SiO}_{2}$ - than the other rocks (Figs. 7a and 7c-7e). Of the studied rocks, the metatexites also have the highest observed normative Q' (Fig. 6c).

The sulphur concentration in the diatexites,
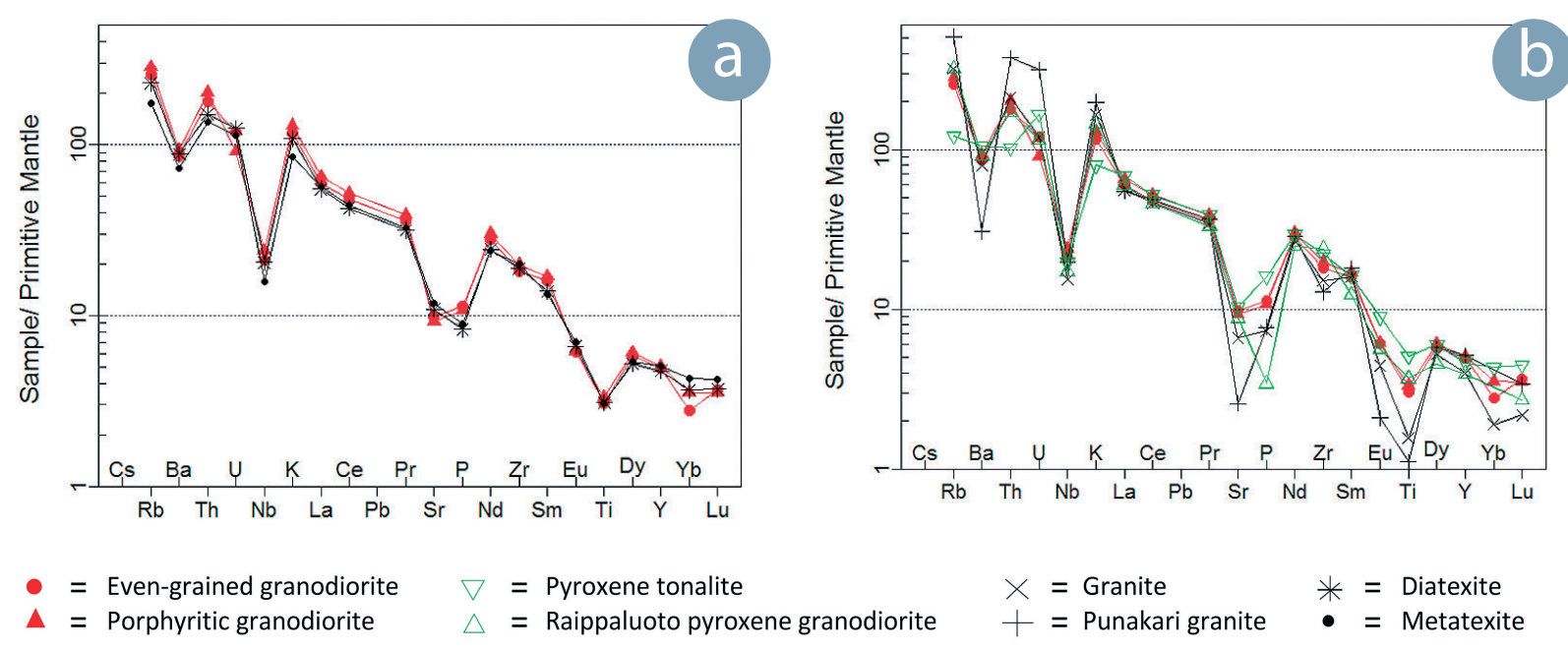

$\Delta=$ Porphyritic granodiorite
- = Even-grained granodiorite $\nabla=$ Pyroxene tonalite

$\triangle=$ Raippaluoto pyroxene granodiorite granodiorites and tonalites is rather high $(-1000$ ppm). In the metatexites and in the Raippaluoto pyroxene granodiorite it is lower $(-500 \mathrm{ppm})$, and in the granites it is often below detection limits (Table 2). The metatexite migmatites have a relatively low $S$ content because sampling avoided the often weathered sulphur- and graphite-bearing intercalations in these rocks. According to Sipilä et al. (2008), the granodiorites comprise -1300 ppm $\mathrm{C}_{\text {tot }}$, but in the granite the concentration is lower, -600 ppm $\mathrm{C}_{\text {tot }}$.

In its entirety, the Vaasa Batholith has a slightly elevated fluorine content $(-0.1 \mathrm{wt} \%)$. The -1.80 Ga topaz pegmatites at the margins of Vaasa Batholith, described by Alviola et al. (2001), are an obvious reflection of this concentration.

In the multielement variation diagrams, many chemical elements in the studied metatexites, diatexites and granodiorites have rather similar anomalies (Fig. 8a). Compared to other rocks, the Punakari granite clearly has the lowest concentrations of $\mathrm{Ba}, \mathrm{Sr}, \mathrm{Ti}$, and $\mathrm{Zr}$, and the highest $\mathrm{Rb}$, Th and $U$ contents (Fig. 8b). The amounts of $\mathrm{Rb}$ and $\mathrm{Th}$ in the pyroxene-bearing tonalites are low. The porphyritic granodiorites have slightly higher $\mathrm{Rb} / \mathrm{Sr}(0.92)$ than the even-grained granodiorites. The Punakari granite has clearly elevated $\mathrm{Rb} / \mathrm{Sr}$ (6.0).

Fig. 8. Average multielement variation compositions. (a) Granodiorites of the Vaasa Batholith, and diatexites and metatexites nearby. (b) Granitoids in the Vaasa Batholith. The data are normalized to the primitive mantle values of Sun and McDonough (1989). 
The Punakari granite analyses plot in the field of fractionated granites in the $\left(\mathrm{Na}_{2} \mathrm{O}+\mathrm{K}_{2} \mathrm{O}\right) / \mathrm{CaO}$ vs. $(\mathrm{Zr}+\mathrm{Nb}+\mathrm{Ce}+\mathrm{Y})$ diagram of Whalen et al. (1987) (Fig. 9a). Notably, the other studied granitoids overlap. The rather high $\mathrm{Rb} / \mathrm{Ba}$ in the Punakari granite indicates that this body represents evolved magmas (Fig. 9b). A majority of the studied granitoids plot in the field of post-collisional granites in the $\mathrm{Rb}$ vs. $(\mathrm{Y}+\mathrm{Nb})$ geotectonic diagram of Pearce (1996).

\subsection{Rare earth elements (REE)}

The porphyritic and even-grained granodiorites have rather similar chondrite-normalized REE patterns with enriched LREE (light rare earth elements) (Fig. 10a). However, individual analyses show that there is a notable dispersion in the HREE (heavy rare earth elements), probable due to the variation in modal garnet (Table 2). The metatexite and diatexite migmatites have relatively similar REE patterns. They also have almost horizontal HREE patterns, but in the diatexites it is slightly lower. The granitoids studied from the Vaasa Batholith have a negative Eu-anomaly (Fig. 10b); the most negative is for the Punakari granite $\left(0.15 \mathrm{Eu} / \mathrm{Eu}^{*}\right)$. The orthopyroxene tonalites have slightly elevated HREE in comparison to the Raippaluoto pyroxene granodiorite, while the granites have the lowest HREE.

The rather large amount (17-20\%) of probable residual biotite (plus accessory phases) in the granodiorites and tonalites may, however, mask any positive Eu anomalies. In terms of the available analyses, the granites have the highest $(\mathrm{La} / \mathrm{Yb}) \mathrm{N}$ $(-21.2)$, while the lowest $(-11.8)$ occurs in the metatexites.

\subsection{Mineral analyses}

Biotite in the granodiorites and orthopyroxene granitoids of the Vaasa Batholith has a high $\mathrm{Mg}$ number (47-61). In the granites, the $\mathrm{Mg}$ number of biotite is lower, the lowest value $(\mathrm{Mg} \#=19)$ been observed in the Punakari granite. The amounts of $\mathrm{TiO}_{2}$ in biotites of the granodiorites and granites are rather similar (2.6-3.4 $\mathrm{wt} \%)$ while in the orthopyroxene-bearing granitoids this value is slightly higher (3.4-5.4 wt\%). Compared to other biotites within the Vaasa Batholith, biotite in the
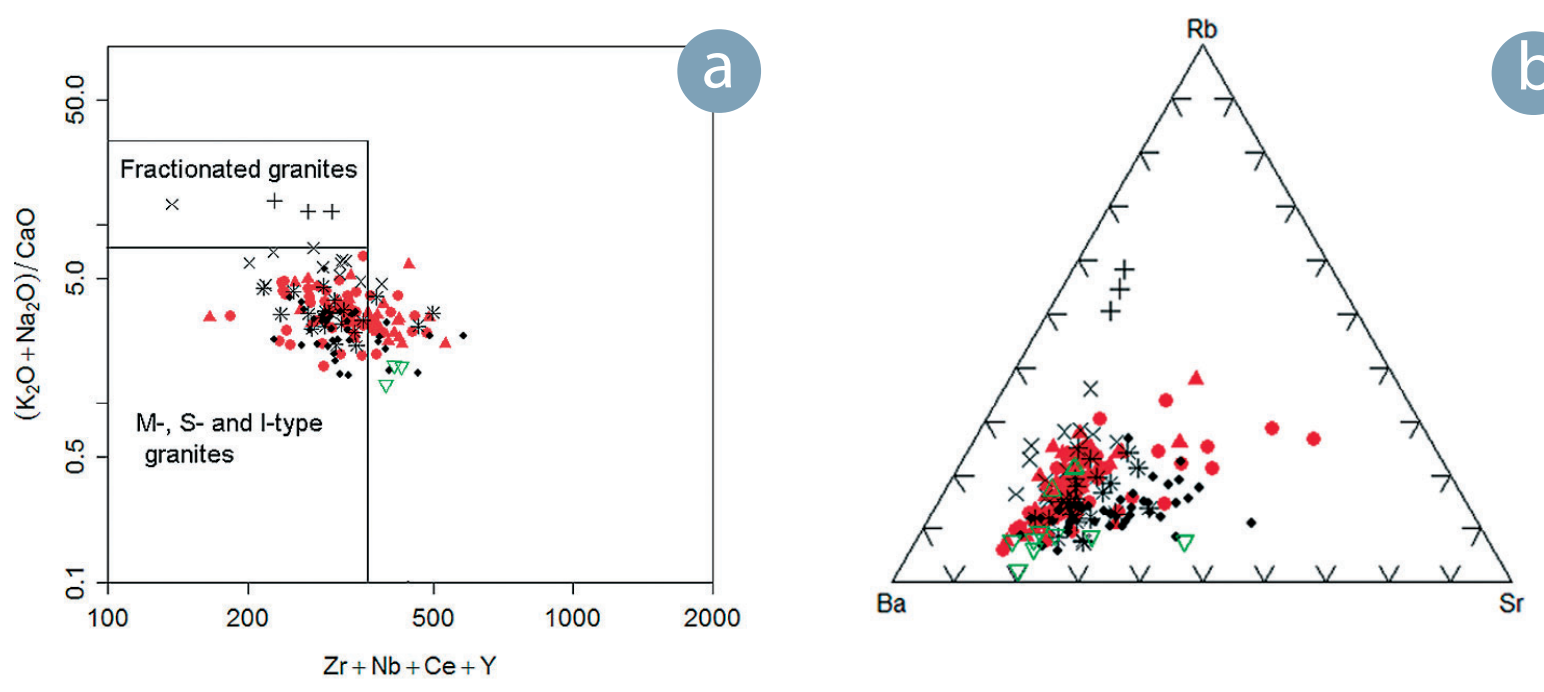

\footnotetext{
- Even-grained granodiorite
}

$\nabla=$ Pyroxene tonalite

$\Delta=$ Raippaluoto pyroxene granodiorite

$$
\begin{array}{ll}
X=\text { Granite } & *=\text { Diatexite } \\
+=\text { Punakari granite } & \bullet=\text { Metatexite }
\end{array}
$$

Fig. 9. Discrimination diagrams for granitoid types in the Vaasa Batholith, and metatexites and diatexites nearby. (a) $\left(\mathrm{Na}_{2} \mathrm{O}+\mathrm{K}_{2} \mathrm{O}\right) / \mathrm{CaO}$ vs. $(\mathrm{Zr}+\mathrm{Nb}+\mathrm{Ce}+\mathrm{Y})$ diagram of Whalen et al. (1987). (b) Ba - Rb - Sr diagram of Thieblemont and Tegyey (1994). 

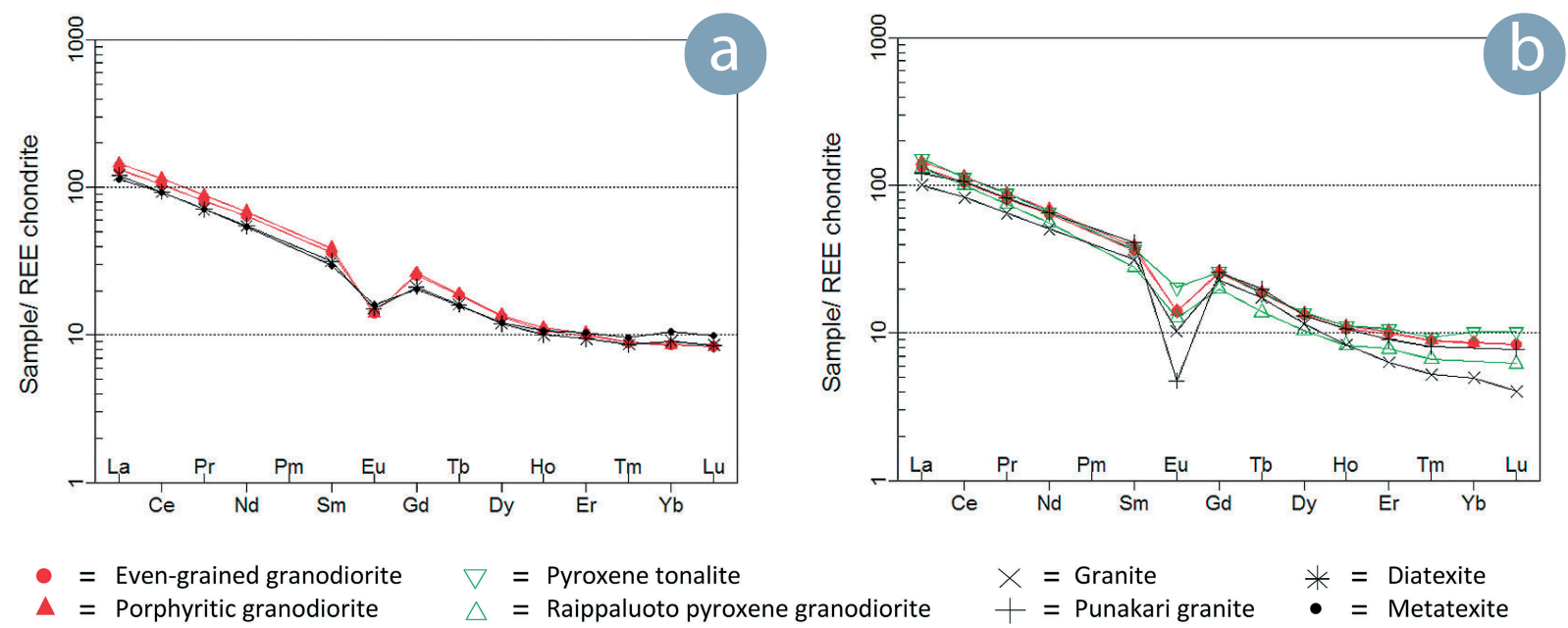

- Even-grained granodiorite

$\nabla=$ Pyroxene tonalite

$+=$ Punakari granite

- = Metatexite

Fig. 10. Average REE compositions. (a) Granodiorites of the Vaasa Batholith, and diatexites and metatexites nearby. (b) Granitoids in the Vaasa Batholith. The data are normalized to the chondrite of Boynton (1984).

granite has a slightly enriched fluorine content $(-1.0$ wt $\%)$. Representative chemical compositions for individual biotite crystals are in Table 3 .

The chemical composition of orthopyroxene in the Vaasa Batholith granitoids differs with $\mathrm{Al}_{2} \mathrm{O}_{3}$ concentrations varying from 0.4 to $3.0 \mathrm{wt} \%$ and a $\mathrm{Mg}$ number between 43 and 55 (Table 3). Orthopyroxene in the garnet-bearing tonalites has slightly higher $\mathrm{Al}$ content than in the garnet-free tonalites. Orthopyroxene in the Raippaluoto granodiorite has clearly less $\mathrm{Al}_{2} \mathrm{O}_{3}$ than the tonalitic types. Garnet in the Vaasa Batholith is generally almandine in composition; its $\mathrm{MgO}$ content in the Vaasa Batholith granodiorites is 3.5-4.0 wt $\%$ and in the pyroxene tonalites $4.2-5.4 \mathrm{wt} \%$ (see also Mäkitie, 2001a; Lehtonen et al., 2005).

Chemically, the biotite, orthopyroxene and garnet in the Vaasa Batholith granodiorites resemble those reported in the nearby diatexites and metatexites (see Lehtonen et al., 2005).

\section{Discussion}

\subsection{Metamorphic reactions and melting}

The extensive metasedimentary sequence in the Pohjanmaa Belt is a natural candidate for the protolith of the Vaasa Batholith. The prominent modal changes in the metatexites of the Pohjanmaa Belt compared to those in the Vaasa Batholith granodiorites are as follows: decrease in biotite from -33 to $-18 \%$, increase in K-feldspar mode from -5 to $-8-12 \%$ and a slight increase in quartz and plagioclase in the granodiorites in comparison to the metatexites (Table 1). At the same time, the volume of garnet often decreases and cordierite practically disappears.

Generally, the aforementioned changes assume that the metatexites of the Pohjanmaa Belt have undergone dehydration melting of biotite, shown by a simplified reaction below (1). However, the amount of possible free $\mathrm{H}_{2} \mathrm{O}$ during likely melting has a notable effect on melting reactions and in the Vaasa region this amount is not known.

$$
\begin{aligned}
& \mathrm{Bt}+\mathrm{Qtz}+\mathrm{Pl} \pm \mathrm{Sil}=\mathrm{Kfs} \pm \mathrm{Grt}+\text { melt } \\
& \mathrm{Bt}+\mathrm{Qtz}+\mathrm{Pl}=\mathrm{Kfs} \pm \mathrm{Opx}+\text { melt }
\end{aligned}
$$

In terms of orthopyroxene-bearing products, the related dehydration reaction should be reaction (2). However, the amount of biotite in the studied granodiorites and pyroxene tonalites remains relatively high. This does not presuppose that these rocks are direct accumulations of leucocratic magma formed by biotite dehydration melting of the Pohjanmaa Belt metapelites, or that the dehydration of protolith here was effective. 
Table 3. Representative electron microprobe analyses of biotite and orthopyroxene from the granitoids of the Vaasa Batholith. Oxygens: 11 (Bt), 6 (Opx). n.a. = not analysed.

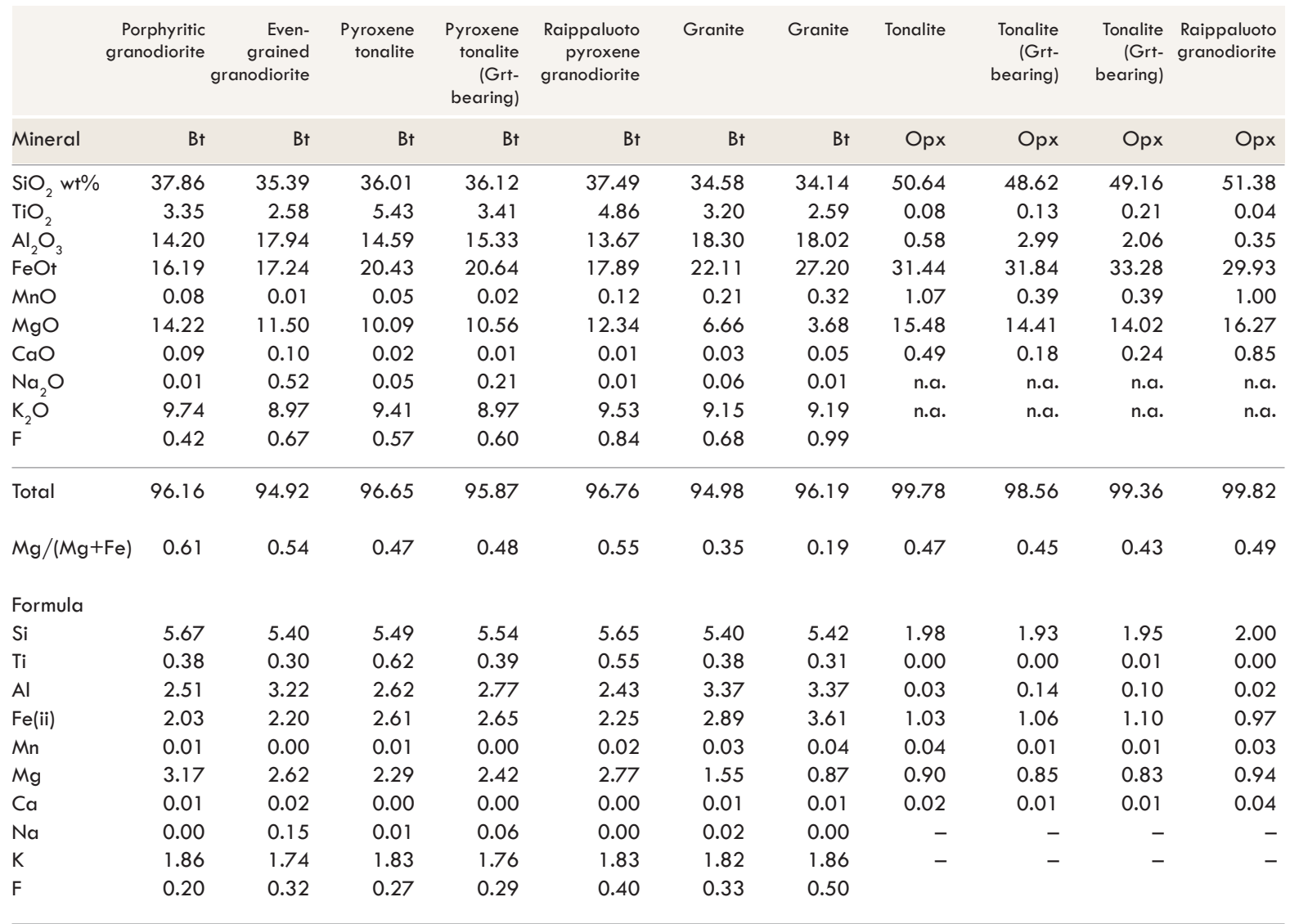

The high $\mathrm{Mg} \#$ and $\mathrm{Ti}$ in biotites of the studied diatexites and in the whole rock chemical compositions (Tables 2 and 3) may have shifted reaction (1) to higher temperatures resulting in a higher "biotite out" temperature (e.g. Stevens et al., 1997). In addition, the elevated fluorine content $(0.4-1.0 \mathrm{wt} \%)$ in the biotite of Vaasa Batholith may also enhance biotite stability at higher temperatures.

Some of the $\mathrm{Mg}$-Fe silicates in the Vaasa Batholith rocks, such as garnet, could represent residual assemblages or peritectic mineral after reaction (1), or even post-anatectic recrystallization. The orthopyroxene (having high $\mathrm{Mg \#}$ and $\mathrm{Al}_{2} \mathrm{O}_{3}$ ) in the Vaasa Batholith compositionally resembles metamorphic orthopyroxene that occurs in the migmatitic country rocks. The graphite- and sulphide-bearing patches in the granodiorites are obvious restites derived from C-and S-bearing intercalations in the Pohjanmaa Belt metasediments.

According to experimental melting of micabearing quartzo-feldspathic rocks studied by Chen and Grapes (2007), the melt formed may extend over wide areas in the alkali-feldspar granite, granite, adamellite, granodiorite and tonalite fields in the Q' vs. ANOR diagram. The Vaasa Batholith granitoids mostly plot in the granite and granodiorite field in the aforementioned diagram (Fig. 6c) and, compositionally, they could have a sedimentary protolith. The lack of sphene and mafic enclaves, but occurrence of monazite in the Vaasa Batholith indicates that the protolith of Vaasa Batholith was pelitic, not intermediate or mafic in composition. In normative $\mathrm{Ab}-\mathrm{Q}$ - Or triangle, the chemical data of the granodiorites and diatexites 
hit near the area of minimum melt compositions (Fig. 11), but the position of metatexites separates from the granodiorites and diatexites.

As shown in Figures $7 \mathrm{a}-7 \mathrm{f}$, most of the granitoids in the Vaasa Batholith plot along a trend, but the metatexites partly plot off the trend or cut it. These chemical differences between the Vaasa Batholith granodiorites and the metatexites of the Pohjanmaa Belt do not support an isochemical reaction between these rocks units.

We suppose that the Vaasa Batholith granodiorites represent a 'magma layer' (see Chen \& Grapes, 2007) in the crust, rather than upwards accumulated melt products after migmatites (Fig. 12). Here, the boundary between diatexites and metatexites indicates a 'magma interface' or 'melting interface (MI)' (see Chen \& Grapes, 2007), which separates convection zone from the conduction zone (metatexites) above. MI refers to the upper surface of a crustal magma layer, physically defined by as the upper limit of a crustal convection layer, marking the contact between magma and rock, and two heat flow modes: convection and conduction. According to the chemical data shown in the previous figures

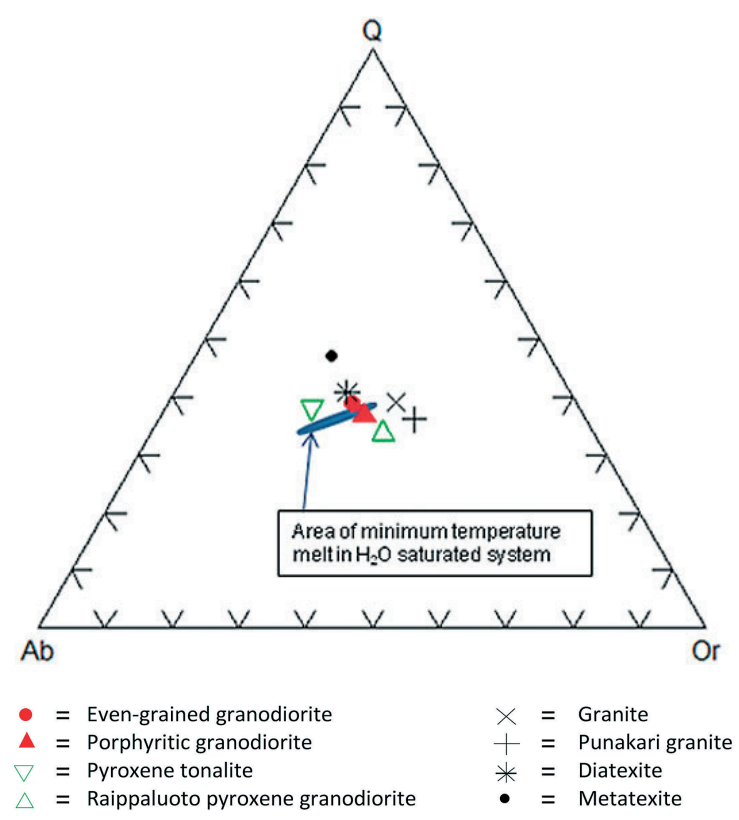

Fig. 11. Normative Ab - Q - Or diagram. Plotted are the average CIPW values for granitoid types in the Vaasa Batholith, and metatexites and diatexites nearby. and to the textural similarities with the granodiorites, the diatexites should mainly be form the inhomogenous magma formed under the MI. Differences among the various granodiorites and diatexites is mainly in rock texture or structure, not in bulk chemical composition.

Many schist relicts found in granodiorites may represent fragments from the conduction zone that have "dropped" into the convection zone below. In other words, the upward thickening of the magma layer (and rising of the MI) has melted the roof rock, but resting some relicts. The older migmatization observed in these pelitic schist relicts (see Sipilä et al., 2008; Fig. 14) was formed earlier in the heat conduction zone above the MI. Convection in the magma layer could also have caused the parallelism in the trends of large relict inclusions in the Vaasa Batholith granodiorites.

Lindh (2005) has presented a thermal model that proposes homogeneous thickening of the lithosphere by collision of island arcs and thrusting at a continental margin resulting in melting of the Bothnian Basin metasedimentary rocks in Sweden. According to Lindh (2005), an initial crustal thickness of $35 \mathrm{~km}$ may give after doubling the crust thickness at a temperature $-50{ }^{\circ} \mathrm{C}$ in excess of melting temperatures.

Based on chemical and isotopic data, Lindh (2005) also suggests that the source of the S-type Härnö granite in Sweden - which resembles the Punakari granite of the Vaasa Batholith - was metasedimentary. Batch melting models also support the concept that granitic magmas forming the Härnö granite can be derived from the Bothnian Basin metasedimentary rocks (Claesson \& Lundqvist, 1995; Fig. 12). The diatexites of the Vaasa region chemically resemble the Härnö quartz-rich metagreywackes used in the aforementioned models.

The almost restite-free Punakari granite could represent magmas ascended to higher crustal levels. The emplacement of "primary" granites can cause partial melting in the fertile crust, with the formation of cool, water-rich, less mobile, restiterich "secondary" regional-aureole granite magmas (see Finger \& Clemens, 1995). However, the Punakari granite is relatively small in size in comparison 
to the extensive Vaasa Batholith granodiorites - too small to cause wide melting. The Mesoproteozoic diabases and Rapakivi granites (e.g. Björk et al., 2007) in the archipelago of Vaasa postdate the formation of the Vaasa Batholith. In the Vaasa region, the source of the locally increased heat budget is not yet well understood.

\subsection{Fractionation}

The Vaasa Batholith magma seems to have undergone slight fractionation (towards lower Sr and $\mathrm{Ba}$ ) from the granodiorites to the granites (Fig. 9b). The diatexites occur on the lower Sr content side unlike the metatexites. Some granite samples have elevated $\mathrm{LaN} / \mathrm{YbN}$ ratio compared to that in other Vaasa Batholith granitoids. Moreover, the HREE (and the amount of garnet in Vöyri granite) are decreased in the former samples in relation to the other.

The Punakari granites fall on the end of the tonalite-granodiorites-granite trend (Figs. 7a-7f). Particularly the $\mathrm{K}_{2} \mathrm{O}+\mathrm{Na}_{2} \mathrm{O} / \mathrm{CaO}$ values of the studied granitoids indicate that the Punakari granite is fractionated (Fig. 9a). However, the Punakari granite differs by texture and chemical composition from the other granites in the Vaasa Batholith. The chemical compositions of the Vöyri and Punakari granites may reflect in situ differentiation of the magma layer rather than different magma sources (see concepts of Chen \& Grapes, 2007).

The orthopyroxene-bearing granitoids on the other hand could represent - due to their higher density and due to gravitational differentiation of restites - compositionally stratified magma layer in slightly deeper part of the convection zone. Moreover, there have apparently occurred slight differences in crystallization conditions, because the dark colour in pyroxene tonalites suddenly changes to light without change in rock texture.

\subsection{Crustal structure}

Seismic reflection profiles indicate that the Svecofennian crust $25 \mathrm{~km}$ northeast of the Vaasa Batholith, near the town of Kokkola, is characterized by a series of prominent reflective bands that have a gentle to moderate southerly dip towards Moho depths in a plane section (Sorjonen-Ward, 2006). Similar gentle bands may, thus, occur beneath the Vaasa Batholith and suggest planar structures and lithological contacts between the studied metatexites, diatexites and granitoids.

Gravitational differentiation of restites within a partial melting region not only results in formation of a magma layer, but could also help to initiate convection within a layer (see Chen \& Grapes, 2007; Fig. 3.13). The convection may also result in vertical compositional variation of the magma layer (see Fig. 12). Moreover, the variation can be reinforced during cooling with fractional crystallization of nearliquidus phases.

The granodiorites of Vaasa Batholith should represent a 'magma layer' of the crust, associated with diapiric exhumation (Fig. 12). The upper limit of this layer is shown by diatexites. There are also diatexite areas within the granodiorite, indicating that the present surface is near the "roof" of the magma layer.

Regionally the Vaasa Batholith area seems to reach $35 \mathrm{~km}$ deep in north and east, but in the middle part it only reaches $10 \mathrm{~km}$ thick (Valtonen et al., 2011). In the south, the extent of the Batholith is limited by an obvious Rapakivi granite massif (Korja et al., 2001).

\subsection{Comparison with nearby granitoids}

Some $70 \mathrm{~km}$ south of Vaasa town the diatexitic granitoids have yielded ages of $\sim 1.82 \mathrm{Ga}$ (Lehtonen et al., 2005). $120 \mathrm{~km}$ west, in Sweden, the $\sim 1.82$ Ga S-type intrusive Härnö granite is probably derived from a metasedimentary source the Bothnian basin (Claesson \& Lundqvist, 1995; Lindh, 2005). These age data postdate the main formation of Vaasa Batholith and indicate that the rate of crustal cooling (and/or exhumation) seems to differ in the Bothnian Basin region.

The Vaasa Batholith differs especially from the nearby, small $\sim 1.88$ Ga tonalite intrusions of the Pohjanmaa Belt and from the extensive 1.89-1.87 


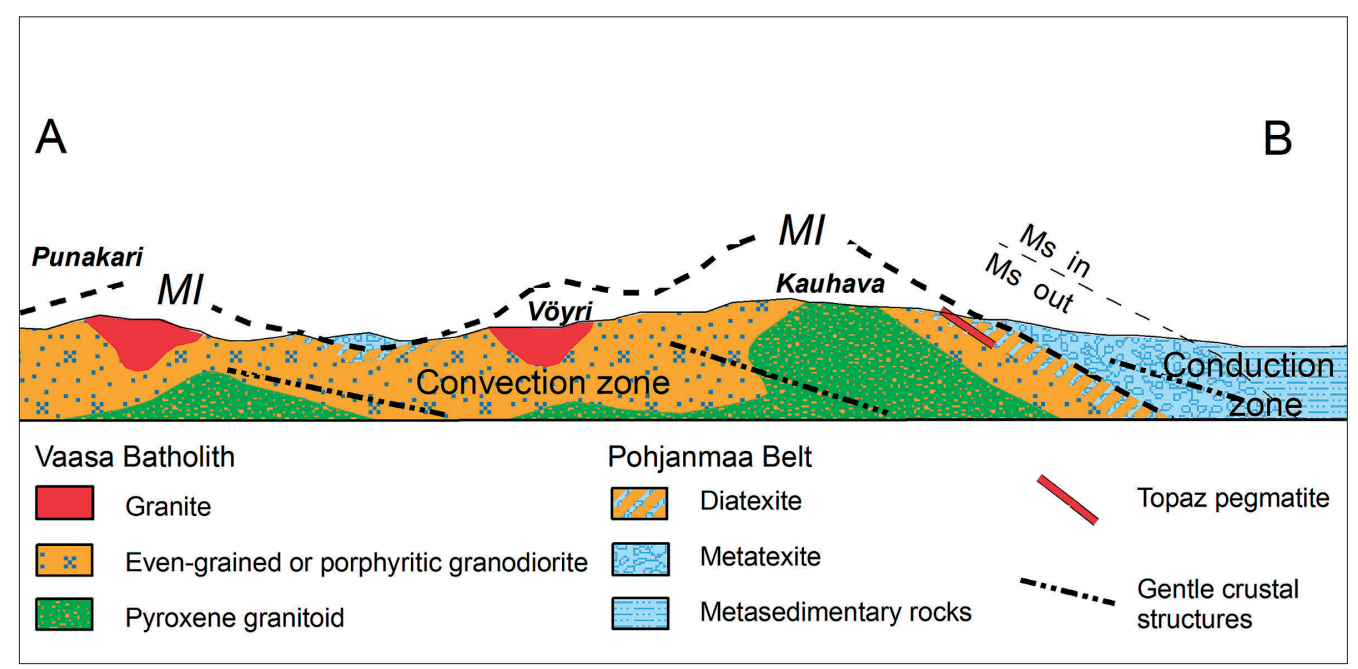

Fig. 12. Schematic $\sim 120 \mathrm{~km}$ long cross section of the upper crust from Punakari granite via Vöyri and Kauhava areas to the Pohjanmaa Belt metasediments. The position of the section is shown by line A$\mathrm{B}$ in Figure 1. $\mathrm{MI}=$ magma interface, $\mathrm{Ms}=$ muscovite in metasedimentary rocks.

Ga of the Central Finland Granitoid Complex (see Vaarma \& Pipping, 1997; Nironen, 2003): i.e. by the absence of hornblende, sphene and mafic enclaves, and by the absence of sharp intrusive contacts against country rocks. Moreover, biotite and orthopyroxene in the Vaasa Batholith granodiorites and tonalites clearly have a higher $\mathrm{Mg}$ number (and $\mathrm{Al}$ content in orthopyroxene) compared to those reported by Elliott et al. (1998) from the postkinematic granitoids of the Central Finland Granitoid Complex (CFGC). These differences indicate that minerals in the Vaasa Batholith granodiorites and pyroxene tonalites do not represent magmatic crystallization from a ferrous source as is the case in the previously mentioned postkinematic granitoids. Gradational contacts between the Vaasa Batholith granodiorites and the Pohjanmaa Belt metatexites indicate that the former is less ascended in the crust than the CFGC intrusions that have sharp contacts - although the Vaasa Batholith granitoids locally resemble those of the CFGC.

\section{Conclusions}

The data presented - together with referred publications - indicate that most of the Vaasa Batholith represents an exhumed magma layer formed by in situ melting of the crust. The lack of sharp concordant or discordant contacts against the supracrustal metatexite migmatites of the Pohjanmaa Belt and the notable overlap in the chemical compositions of the main phase (granodiorites) of the Vaasa Batholith and the diatexites are important evidence. The granodiorites - major part of the magma layer - together with the surrounding diatexites are separated from the metatexites by a magma interface (melting interface, MI) (see Chen \& Grapes, 2007), which separates convection zone from the conduction zone (Fig. 12).

Metatexites represent partially melted rocks formed above the MI and diatexites should mainly be from the inhomogenous magma formed under the MI. The difference among the granodiorites and diatexites is predominantly in rock texture or structure, not in bulk composition.

The bulk composition of tonalites, granodiorites and granites evolves along the same path but metatexites are beyond or cutting the path (Fig. 7). This supports that the main phase (granodiorite) of the Vaasa Batholith is not an isochemical melting product of the near metatexites. Chemical data indicate that the granites within the Vaasa Batholith are fractionated and evolved. The granites may represent in situ differentiation rather than 
derivation from different source. In comparison to the granodiorites, the pyroxene tonalites in the Vaasa Batholith could partly be formed by gravitational development of a stratified intermediate layer within the magma layer, associated with small differences in crystallization conditions.

The Vaasa Batholith is an exceptional type example of the voluminous, diverse and mostly ascended intrusive granitoids in the Svecofennian Orogen in Finland.

\section{Acknowledgements}

We wish to thank Matti I. Lehtonen, Reijo Niemelä, Markus Torssonen, Tuomo Turunen, Markku Väisänen and Petri Virransalo for their fieldwork and guidance in the study region. Many discussions with Niilo Kärkkäinen and Seppo I. Lahti were fruitful. The authors are also grateful to Olav Eklund, Pentti Hölttä, Annakaisa Korja, Matti Kurhila and O. Tapani Rämö for their valuable comments and structural observations during the MIDCRUST-project SA-139035 excursion in the Vaasa region in springtime 2012. Special thanks go to Kalevi Rasilainen, Raimo Lahtinen and Th.J. Bornhorst for the lithogeochemical database of Geological Survey of Finland. Our gratitude goes also to Lassi Pakkanen who carried out the microprobe analyses.

\section{References}

Alviola, R., Mänttäri, I., Mäkitie, H. \& Vaasjoki, M. 2001. Svecofennian rare-element granitic pegmatites of the Ostrobothnia region, western Finland: their metamorphic environment and time of intrusion. In: Mäkitie, H. (Ed.) Svecofennian granitic pegmatites (1.86-1.79 Ga) and quartz monzonite $(1.87 \mathrm{Ga})$, and their metamorphic environment in the Seinäjoki region, western Finland. Geological Survey of Finland, Special Paper 30, 9-29.

Björk, L., Kero, L., Kujala, H. \& Sipilä, P. 2007. Bedrock geology of the Kvarken area. 1: 200 000. Geological Survey of Finland, Geological Survey of Sweden.

Boynton, W.V. 1984. Cosmochemistry of the rare earth elements: meteorite studies. In: Henderson, P. (ed.) Rare Earth Element Geochemistry. Elsevier, Amsterdam, pp. 63-114.

Brown, M. 1973. The definition of Metatexis, Diatexis and Migmatites. Proceedings of the Geologists Association 84, 371-382.

Brown, M. 2008. Granites, migmatites and residual granulites: relationships and processes. In: Sawyer, E.W. \& Brown, M. (Eds.) Working with Migmatites. Mineralogical Association of Canada, Short Course 38, 97-144.

Chen, G.N. \& Grapes, R. 2003. In-situ melting model for granite formation: evidence from SE China. International Geological Review 45, 611-622.

Chen, G.N. \& Grapes, R. 2007. Granite genesis: In-Situ Melting and Crustal Evolution. Springler. 278 p.

Claesson, S. \& Lundqvist, T. 1995. Origins and ages of Proterozoic granitoids in the Bothnian Basin, central Sweden; isotopic and geochemical constraints. Lithos 36, 115140.

Cox, K.G., Bell, J.D. \& Pankhurst, R.J. 1979. The Interpretation of Igneous Rocks. Allen and Unwin, London. 450 p.

De la Roche, H., Leterrier, J., Granclaude, P. \& Marchal, M. 1980. A classification of volcanic and plutonic rocks using R1-R2 diagrams and major element analyses - its relationships and current nomenclature. Chemical Geology 29, 183-210.

Elliott, B.A., Rämö, O.T. \& Nironen, M. 1998. Mineral chemistry constraints on the evolution of the 1.88-1.87 Ga post-kinematic granite plutons in the Central Finland Granitoid Complex. Lithos 45, 109-129.

Finger, F. \& Clemens, J.D. 1995. Migmatization and "secondary" granitic magmas: effects of emplacement and crystallization of "primary" granitoids in Southern Bohemia, Austria. Contribution on Mineralogy and Petrology 120, 311-326.

Gaál, G. \& Gorbatchev, R. 1987. An outline of the Precambrian evolution of the Baltic Shield. Precambrian Research 35, $15-52$.

Helovuori, O. 1949. Havaintoja Vähänkyrön alueen kallioperästä. [Observations of the bedrock in the Vähäkyrö area]. M.Sc thesis. University of Helsinki, Department of Geology. 52 p. (in Finnish)

Hietanen, A. 1975. Generation of potassium-poor magmas in the northern Sierra Nevada and the Svecofennian of Finland. Journal of Research of the U.S. Geological Survey 3, 631-645.

Isohanni, M. 1985. The Oravainen nickel occurrence in western Finland. In: Papunen, H. \& Gordunov, G.I. (Eds.) Nickel copper deposits of the Baltic Shield and Scandinavian Caledonides. Geological Survey of Finland, Bulletin 333, 189-210.

Kähkönen, Y. 2005. Svecofennian supracrustal rocks. In: Lehtinen, M., Nurmi, P.A. \& Rämö, O.T. (Eds.) Precambrian geology of Finland. Key to the evolution of the Fennoscandian Shield. Developments in Precambrian geology 14. Amsterdam: Elsevier, pp. 343-405.

Kärkkäinen, N. 1993. Etelä-Pohjanmaan liuskejakson malmipotentiaali kallioperän geokemian perusteella. [Ore potential of South Pohjanmaa Schist Belt based on lithogeochemistry]. Lic. Ph. thesis. Department of Geology, University of Oulu. 233 p. (in Finnish)

Koistinen, T., Stephens, M.B., Bogatchev, V., Nordgulen, Ø., Wennerström, M. \& Korhonen, J. 2001. Geological map of the Fennoscandian Shield, scale 1:2 000 000. Geological 
Surveys of Finland, Norway and Sweden and the NorthWest Department of Natural Resources of Russia.

Korja, A. \& Heikkinen, P. \& Aaro, S. 2001. Crustal structure of the northern Baltic Sea palaeorift. Tectonophysics 331, 341-358.

Korhonen, J.V., Aaro, S., All, T., Elo, S., Haller, L.Å., Kääriäinen, J., Kulinich, A., Skilbrei, J.R., Solheim, D., Säävuori, H., Vaher, R., Zhdanova, L. \& Koistinen, T. 2002. Bouguer anomaly map of the Fennoscandian Shield: IGSN 71 gravity system, GRS80 normal gravity formula. Bouguer density $2670 \mathrm{~kg} / \mathrm{m}^{3}$, terrain correction applied. Anomaly continued upwards to $500 \mathrm{~m}$ above ground : scale 1 : 2000 000. Espoo : Trondheim : Uppsala : Moscow: Geological Survey of Finland : Geological Survey of Norway : Geological Survey of Sweden : Ministry of Natural Resources of Russia.

Korsman, K., Koistinen, T., Kohonen, J., Wennerström, M., Ekdahl, E., Honkamo, M., Idman, H. \& Pekkala, Y. (Eds.) 1997. Suomen kallioperäkartta - Berggrundskarta över Finland - Bedrock map of Finland 1:1 000 000. Espoo: Geologian tutkimuskeskus - Geological Survey of Finland.

Lahtinen, R., Korja, A. \& Nironen, M. 2005. Paleoproterozoic tectonic evolution. In: Lehtinen, M., Nurmi, P.A. \& Rämö, O.T. (Eds.) Precambrian geology of Finland. Key to the evolution of the Fennoscandian Shield. Developments in Precambrian geology 14. Amsterdam: Elsevier, pp. 481531.

Laitakari, A. 1942. Vaasa. Suomen geologinen yleiskartta 1: 400 000, kivilajikartan selitys, lehti B3 - Vaasa. Map explanation for the geological map sheet B3 Vaasa. Geologian tutkimuskeskus - Geological Survey of Finland. 66 pp. (in Finnish)

Lehtinen, M., Nurmi, P.A. \& Rämö, O.T. (Eds.) 2005. Precambrian geology of Finland. Key to the evolution of the Fennoscandian shield. Developments in Precambrian geology 14. Amsterdam: Elsevier. 736 pp.

Lehtonen, M.I., Kujala, H., Kärkkäinen, N., Lehtonen, A., Mäkitie, H., Mänttäri, I., Virransalo, P. \& Vuokko, J. 2005. Etelä-Pohjanmaan liuskealueen kallioperä. Summary: PreQuaternary rocks of the South-Ostrobothnian Schist Belt. Geologian tutkimuskeskus, Tutkimusraportti-Geological Survey of Finland, Report of Investigation 158, 1-125 p. 1 App. (in Finnish)

Le Maitre, R.W. (Ed.) 1989. A classification of igneous rocks and glossary of terms: recommendations of the International Union of Geological Sciences Subcommission on the systematic of igneous rocks. Blackwell Scientific Publications. 192 pp.

Lindh, A. 2005. Origin of chemically distinct granites in a composite intrusion in east-central Sweden: geochemical and geothermal constraints. Lithos 80, 249-266.

Lundqvist, T. 1987. Early Svecofennian stratigraphy of southern and central Norland, Sweden, and the possible existence of an Archaean basement west of the Svecokarelides. In:
Gaál, G. \& Gorbatschev, R. (Eds.) Precambrian Geology and Evolution of the Central Baltic Shield. Precambrian Research 35, 343-352.

Lundqvist, T., Bøe, R., Kousa, J., Lukkarinen, H., Lutro, O., Roberts, D., Solli, A., Stephens, M. \& Weihed, P. 1996. Bedrock map of the Central Fennoscandia. Scale 1:1 000 000.Geological Surveys of Finland (Espoo), Norway (Trondheim) and Sweden (Uppsala).

Lundqvist, T. \& Autio, S. (Eds.) 2000. Description to the bedrock map of central Fennoscandia (Mid-Norden). Geological Survey of Finland, Special Paper 28, 1-176.

Mehnert, K.R. 1968. Migmatites and the Origin of Granitic rocks. Elsevier Publishing Company, Amsterdam, London, New York. 393 p.

Mäkitie, H. 1999. Structural analysis and metamorphism of Palaeoproterozoic metapelites in the Seinäjoki-Ilmajoki area, western Finland. Bulletin of the Geological Society of Finland 71, 305-328.

Mäkitie, H., 2001a. Eastern margin of the Vaasa Migmatite Complex, Kauhava, western Finland: preliminary petrography and geochemistry of the diatexites. Bulletin of the Geological Society of Finland 73, 35-46.

Mäkitie, H. (Ed.) 2001b. Svecofennian granitic pegmatites $(1.86-1.79 \mathrm{Ga})$ and quartz monzonite $(1.87 \mathrm{Ga})$, and their metamorphic environment in the Seinäjoki region, western Finland. Geological Survey of Finland, Special Paper 30, 1-93. 5 App.

Mäkitie, H., Kärkkäinen, N., Lahti, S.I. \& Lehtonen, M.I. 1999. Chemical and modal composition of granitoids in three different geological units, South Pohjanmaa, western Finland. In: Autio, S. (Ed.) Current Research 1997-1998. Geological Survey of Finland, Special Paper 27, 7-19.

Mäkitie, H., Sipilä, P., Lehtonen, M.I., Kujala, H., Lahtinen, R. \& Virransalo, P. 2008. Diatexite-granite connection: the origin of the $1.88 \mathrm{Ga}$ Vaasa granite, Fennoscandian Shield [Electronic resource]. In: 33rd International Geological Congress, 6-14 August 2008, Oslo, Norway: abstract CD-ROM. 1 p.

Nironen, M. 1997. The Svecofennian Orogen: a tectonic model. Precambrian Research 86, 21-44.

Nironen, M. 2003. Keski-Suomen granitoidikompleksi. Karttaselitys. Summary: Central Finland Granitoid Complex Explanation to a map. Geological Survey of Finland, Report of Investigation 157, 1-45. 1 appended map.

Nironen, M., Elliott, B.A. \& Rämö, O.T. 2000. 1.88-1.87 Ga post-kinematic intrusions of the Central Finland Granitoid Complex: a shift from C-type to A-type magmatism during lithospheric convergence. Lithos 53, 37-58.

Nironen, M., Lahtinen, R. \& Koistinen, T. 2002. Suomen geologiset aluenimet - yhtenäisempään nimikäytäntöön! Summary: Subdivision of Finnish bedrock - an attempt to harmonize terminology. Geologi 54, 8-14.

Pearce, J. 1996. Sources and settings of granitic rocks. Episodes $19,120-125$. 
Rasilainen, K., Lahtinen, R. \& Bornhorst, T.J. 2007. The Rock Geochemical Database of Finland Manual. Geological Survey of Finland, Report of Investigation 164, 1-38.

Saksela, M. 1935. Über den geologischen Bau SüdOstrobothniens. Bulletin de la Commission Géologique Finlande 110, 1-35. (in German)

Sawyer, E. 2008. Atlas of Migmatites. The Canadian Mineralogist, Special Publication 9. NRC Research Press, Ottawa; Ontario, Canada. 371 pp.

Sipilä, P., Kujala, H. \& Torssonen, M. 2008. Oravaisten-Lapuan-Alahärmän kallioperä. Abstract: Pre-Quaternary rocks of the Oravainen-Lapua-Alahärmä area. Geological Survey of Finland, Report of Investigation 170, 1-40. 4 Appendixes including 1:200 000 scale geological map.

Sorjonen-Ward, P. 2006. Geological and structural framework and preliminary interpretation of the FIRE 3 and FIRE 4 reflection seismic profiles, central Finland. In: Kukkonen, I. \& Lahtinen, R. (Eds.) Finnish reflection Experiment FIRE 2001-2005. Geological Survey of Finland, Special Paper 43, 105-159.

Stevens, G., Clemens, J.D. \& Droop, G.T.R. 1997. Melt production during granulite-facies anatexis: experimental data from primitive metasedimentary protoliths. Contribution to Mineralogy and Petrology 128, 352-370.

Streckeisen, A. 1976. To each plutonic rocks its proper name. Earth-Science Reviews 12, 1-33.

Streckeisen, A. \& Le Maitre, R.W. 1979. A chemical approximation to the modal QAPF classification of the igneous rocks. Neues Jahrbuch für Mineralogie Abhandlungen 136, 169-206.

Sun, S.S. \& McDonough, W.E. 1989. Chemical and isotopic systematic of oceanic basalts: implications for mantle composition and processes. Geological Society Special Publications 42, 313-345.

Thieblemont, D. \& Tegyey, M. 1994. Une Discrimination geochimique des roches differenciees temoin de la diversite d'origine et de situation tectonique des magmas calcoalcalins. [Geochemical discrimination of differentiated magmatic rocks attesting for the variable origin and tectonic setting of calc-alkaline magmas]. Comptes Rendus de l'Academie des Sciences, Serie II. Sciences de la Terre et des Planetes, 319, 87-94. (in French)

Vaarma, M. \& Pipping, F. 1997. Alajärven ja Evijärven karttaalueiden kallioperä. Summary: Pre-Quaternary rocks of the Alajärvi and Evijärvi map-sheet areas. Suomen geologinen kartta 1:100 000 : kallioperäkarttojen selitykset lehdet 2313 ja 2314. Espoo: Geologian tutkimuskeskus. 83 p.

Vaasjoki, M. \& Sakko, M. 1988. The evolution of the RaaheLadoga zone in Finland: isotopic constraints. In: Korsman, K. (Ed.) Tectono-metamorphic evolution of the RaaheLadoga zone. Geological Survey of Finland, Bulletin 343, 7-32.

Valtonen, O. 2011. Pohjanmaan kompleksin tulkinta painovoimamallinnuksen ja seismisten aineistojen avulla. [Interpretation of the Bothnian Complex by gravimetric modeling and seismic data]. MSc thesis. University of Helsinki, Department of Physics. 73 p. 3 App. (in Finnish)

Valtonen, O., Korja, A. \& Elo, S. 2011. Pohjanmaan kompleksin tulkinta 2.5D-painovoimamallinnuksen ja seismisten aineistojen avulla. [Interpretation of the Bothnian Complex by $2.5 \mathrm{D}$ gravimetric modeling and seismic data]. In: XXV Geofysiikan päivät Oulussa 11.12.05.2011. Oulu: Geofysiiikan Seura, 111-114. (in Finnish)

Väyrynen, H. 1923. Petrologische Untersuchungen der granitodioritischen Gesteine Süd-Ostbothnians. Bulletin de la Commission Géologique de Finlande 57, 1-77. (in German)

Väyrynen, H. 1936. Über die Altersverhältnisse der Granite von Süd-Finnland und Pohjanmaa. Bulletin de la Commission Géologique de Finlande 115, 251-266. (in German)

Vernon, R.H. \& Collins, W.J. 1988. Igneous microstructures in migmatites. Geology 16, 1126-1129.

Whalen, J.B., Currie, K.L. \& Chappell, B.W. 1987. A type granites. Geochemical characteristics, discrimination and petrogenesis. Contributions to Mineralogy and Petrology 95, 407-419.

White, R.W., Powell, R. \& Holland T.J.B. 2001. Calculation of partial melting equilibria in the system $\mathrm{CaO}-\mathrm{Na}_{2} \mathrm{O}$ $\mathrm{K}_{2} \mathrm{O}-\mathrm{FeO}-\mathrm{MgO}-\mathrm{Al}_{2} \mathrm{O}_{3}-\mathrm{SiO}_{2}-\mathrm{H}_{2} \mathrm{O}$ (CNKFMASH). Journal of Metamorphic Geology 19, 139-154.

Wyllie, P.J. 1983. Experimental studies on biotite- and muscovite-granites and some crustal magmatic sources. In: Altherton, M.P. \& Gribble, C.D. (Eds) Migmatites, Melting and Metamorphism. Nantwich, Cheshire, Shiva, pp. 12-26. 


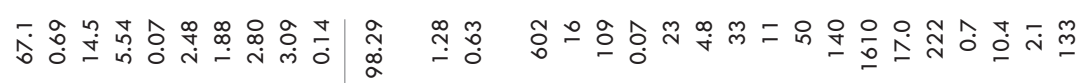

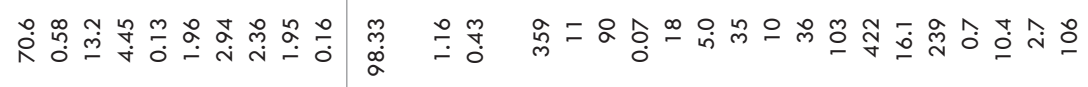

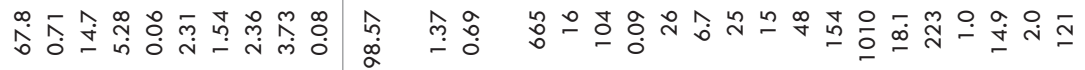

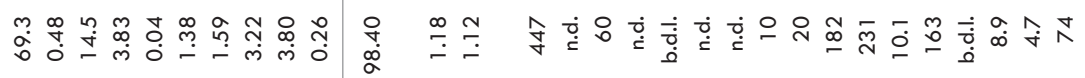

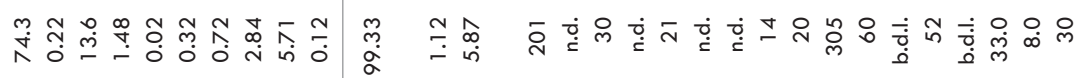

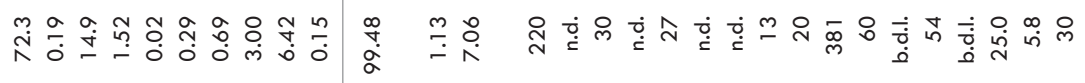

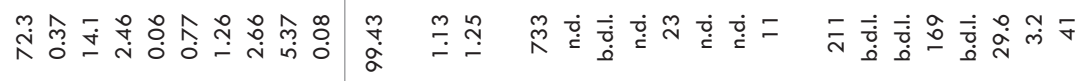

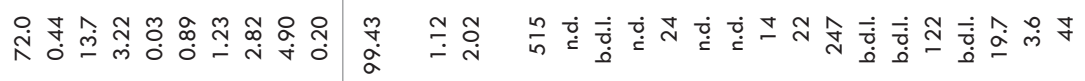

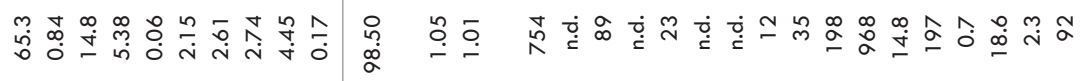

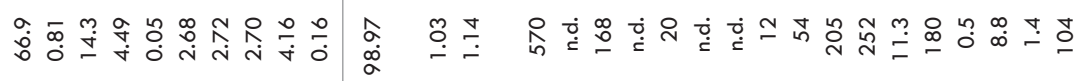

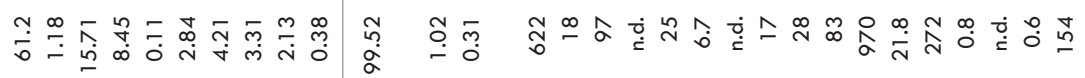

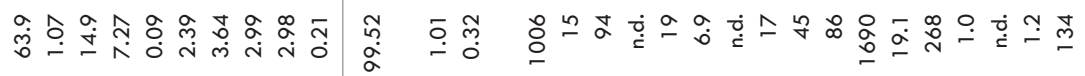

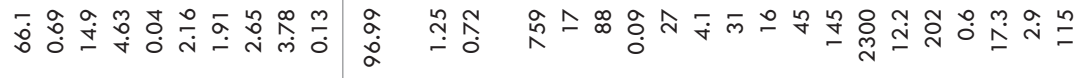

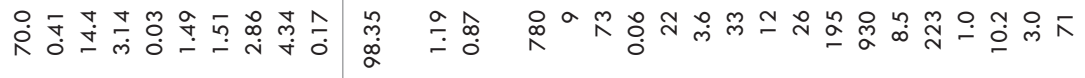

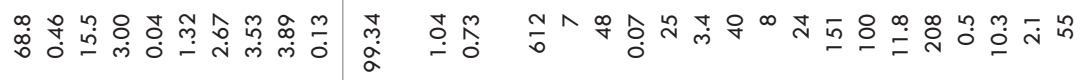

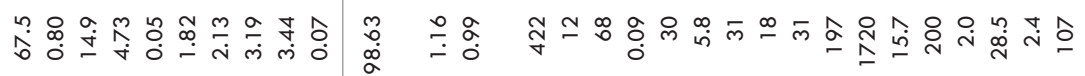

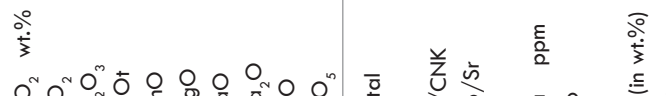

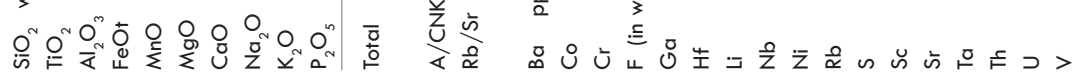




\begin{tabular}{|c|c|c|c|c|c|}
\hline 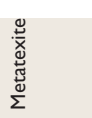 & 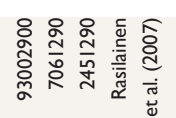 & $\stackrel{\sim}{\sim} \circ \bar{\alpha}$ & 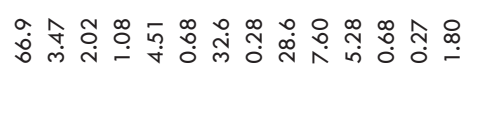 & 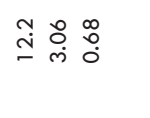 & \\
\hline$\frac{\mathscr{g}}{\mathrm{x}}$ & 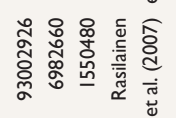 & 용 & 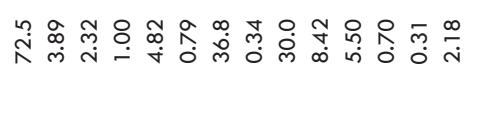 & $\stackrel{\square}{=} \frac{\infty}{\dot{m}} \stackrel{0}{0}$ & \\
\hline 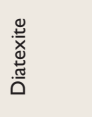 & 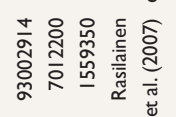 & m을 & 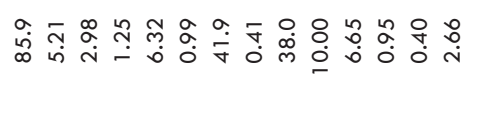 & 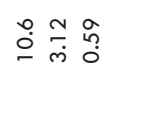 & \\
\hline 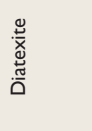 & 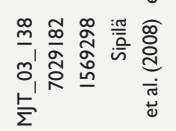 & 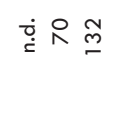 & 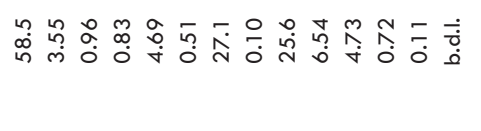 & 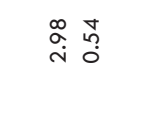 & \\
\hline 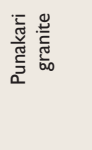 & 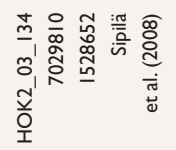 & 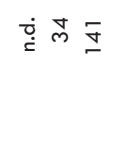 & 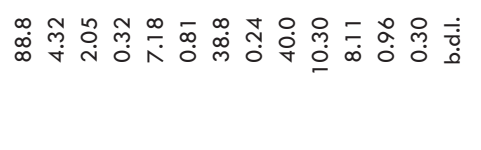 & $\stackrel{\text { İ }}{\stackrel{m}{0}}$ & \\
\hline 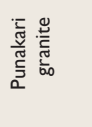 & 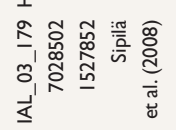 & 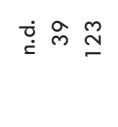 & 员 & 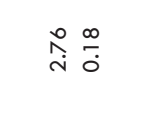 & \\
\hline : & 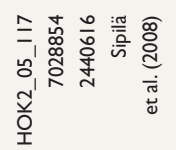 & $\underset{\dot{c}}{\dot{c}}$ Ђ $\stackrel{\infty}{\stackrel{\infty}{\sigma}}$ & a & 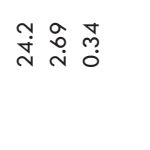 & \\
\hline 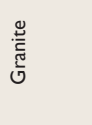 & 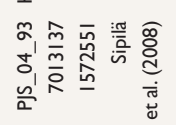 & $\stackrel{\dot{\epsilon}}{\dot{e}}: \circ \stackrel{\circ}{\circ}$ & 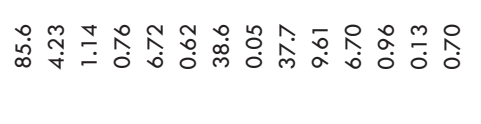 & 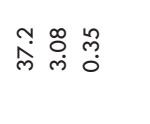 & \\
\hline 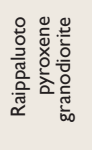 & 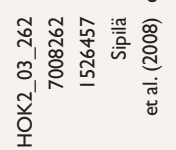 & $\underset{\dot{c}}{\dot{c}} \widehat{\infty} \stackrel{\infty}{\sim}$ & 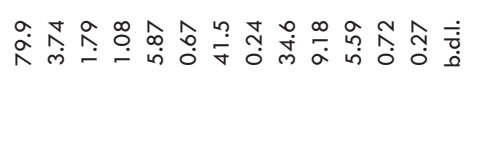 & 虫 & \\
\hline 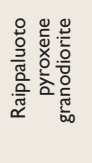 & 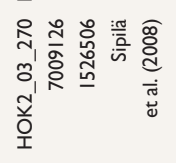 & 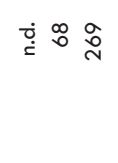 & 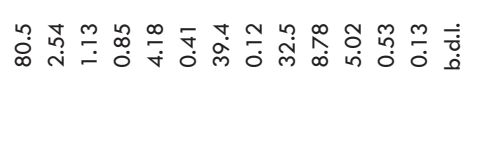 & 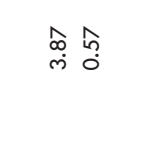 & \\
\hline 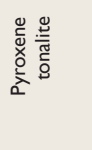 & 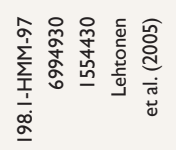 & 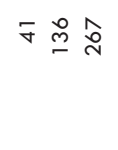 & 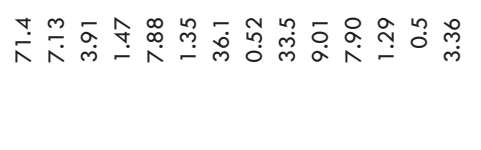 & $\stackrel{\infty}{\wedge} \stackrel{\infty}{\sim} \stackrel{\hat{n}}{0}$ & \\
\hline 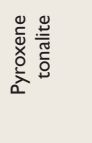 & 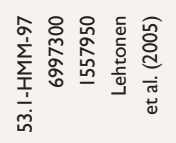 & $\stackrel{\infty}{\sim} \stackrel{\circ}{\circ} \stackrel{\infty}{\sim}$ & 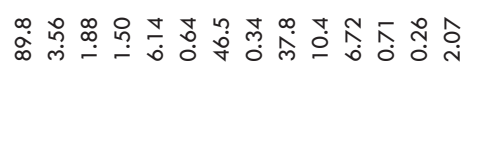 & $\overline{\underline{\varphi}} \underset{\sim}{\stackrel{m}{N}}$ & \\
\hline 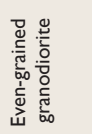 & 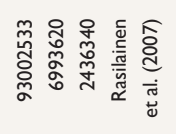 & $\bar{\sim} \stackrel{\circ}{\stackrel{\infty}{\infty}}$ & 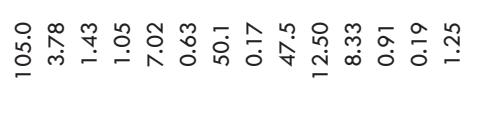 & 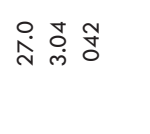 & \\
\hline 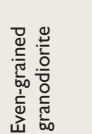 & 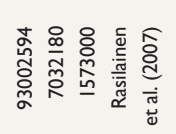 & $=\cong \stackrel{n}{\Omega}$ & 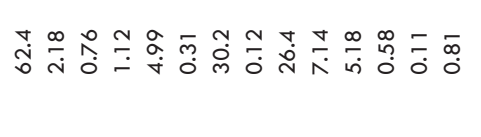 & 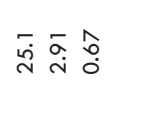 & 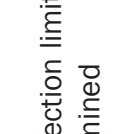 \\
\hline 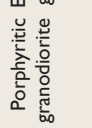 & 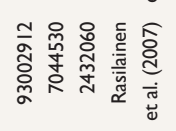 & ํํㅛ & 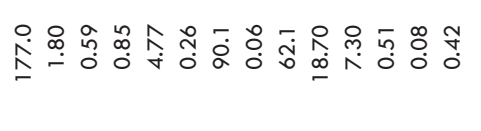 & 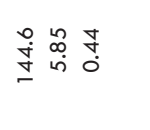 & $\begin{array}{ll}\frac{\Phi}{0} & \frac{E}{0} \\
0 & 0 \\
0 & 0 \\
3 & 0 \\
\frac{0}{0} & 0\end{array}$ \\
\hline 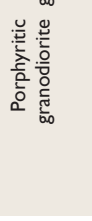 & 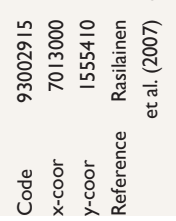 & $\begin{array}{l}\dot{m} \stackrel{\infty}{\alpha} \\
>\mathbb{N}\end{array}$ & 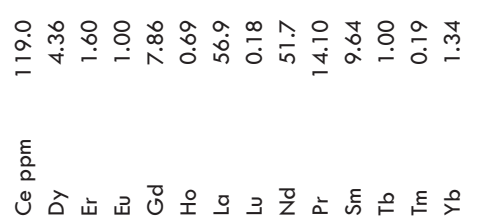 & 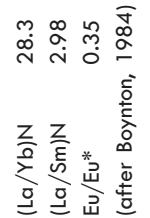 & 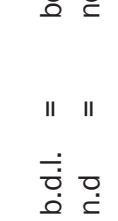 \\
\hline
\end{tabular}

